\title{
Genetic Deletion of Cadm4 Results in Myelin Abnormalities Resembling Charcot-Marie-Tooth Neuropathy
}

\author{
Neev Golan, ${ }^{1}$ Elena Kartvelishvily, ${ }^{1}$ Ivo Spiegel, ${ }^{1}$ Daniela Salomon, ${ }^{1}$ Helena Sabanay, ${ }^{1,2}$ Katya Rechav, ${ }^{2}$ \\ Anya Vainshtein, ${ }^{1}$ Shahar Frechter, ${ }^{1}$ Galia Maik-Rachline, ${ }^{1}$ Yael Eshed-Eisenbach, ${ }^{1}$ Takashi Momoi, ${ }^{3}$ and Elior Peles ${ }^{1}$ \\ ${ }^{1}$ Department of Molecular Cell Biology, Weizmann Institute of Science, Rehovot 76100, Israel, ${ }^{2 E l e c t r o n ~ M i c r o s c o p y ~ U n i t, ~ W e i z m a n n ~ I n s t i t u t e ~ o f ~ S c i e n c e, ~}$ \\ Rehovot 76100, Israel, and ${ }^{3}$ Center for Medical Science, International University of Health and Welfare, Kitakanemaru, Ohtawara, Tochigi, Japan
}

The interaction between myelinating Schwann cells and the axons they ensheath is mediated by cell adhesion molecules of the Cadm/ $\mathrm{Necl} /$ SynCAM family. This family consists of four members: Cadm4/Necl4 and Cadm1/Necl2 are found in both glia and axons, whereas $\mathrm{Cadm} 2 / \mathrm{Necl} 3$ and $\mathrm{Cadm} 3 / \mathrm{Necl} 1$ are expressed by sensory and motor neurons. By generating mice lacking each of the Cadm genes, we now demonstrate that Cadm4 plays a role in the establishment of the myelin unit in the peripheral nervous system. Mice lacking Cadm4 (PGK-Cre/Cadm4 $4^{f l f l}$ ), but not Cadm1, Cadm2, or Cadm3, develop focal hypermyelination characterized by tomacula and myelin outfoldings, which are the hallmark of several Charcot-Marie-Tooth neuropathies. The absence of Cadm4 also resulted in abnormal axon-glial contact and redistribution of ion channels along the axon. These neuropathological features were also found in transgenic mice expressing a dominant-negative mutant of Cadm4 lacking its cytoplasmic domain in myelinating glia $\operatorname{Tg}(m b p$-Cadm4dCT), as well as in mice lacking Cadm4 specifically in Schwann cells $\left(\mathrm{DHH}-\mathrm{Cre} / \mathrm{Cadm} 4^{\mathrm{fl} / \mathrm{fl}}\right)$. Consistent with these abnormalities, both PGK-Cre/Cadm4 ${ }^{f l f l}$ and $\operatorname{Tg}(m b p$-Cadm4dCT $)$ mice exhibit impaired motor function and slower nerve conduction velocity. These findings indicate that Cadm4 regulates the growth of the myelin unit and the organization of the underlying axonal membrane.

\section{Introduction}

Peripheral nerve myelin is a specialized multilamellar membrane produced by Schwann cells that spirals around the axon. The myelin units (internodes) are separated from each other by a nonmyelinated gap known as the node of Ranvier (Jessen and Mirsky, 2005). This configuration allows fast saltatory propagation of action potentials along myelinated axons. The myelin unit comprises areas of compact and noncompact myelin. The latter are located at the paranodal loops, Schmidt-Lanterman incisures, and the inner and outer mesaxons (Scherer and Arroyo, 2002). Noncompact myelin contains tight, gap, and adherens junctions (Poliak et al., 2002; Spiegel and Peles, 2002). The complex architecture of the myelin unit depends on various cell adhesion molecules (CAMs) that are localized to specific membrane contact sites present within the unit (Fannon et al., 1995; Altevogt et al., 2002; Miyamoto et al., 2005; Scheiermann et al., 2007; Kikuchi et

Received Feb. 6, 2013; revised April 22, 2013; accepted May 15, 2013.

Author contributions: N.G., E.K., I.S., and E.P. designed research; N.G., E.K., I.S., D.S., H.S., K.R., A.V., S.F., G.M.-R., and Y.E.-E. performed research; T.M. contributed unpublished reagents/analytic tools; N.G., E.K., I.S., K.R., S.F., and Y.E.-E. analyzed data; E.P. wrote the paper.

This work was supported by the National Institutes of Health Grant NS50220, the Israel Science Foundation, the Minerva Foundation, the Adelson Medical Research Foundation, and the Moskowitz Center for Imaging at the Weizmann Institute. E.P. is the Incumbent of the Hanna Hertz Professorial Chair for Multiple Sclerosis and Neuroscience. We thank Dr. Alan Peterson for the MBP promoter construct, Veronique Amor for critical comments on the manuscript, and Raffi Saka and the team of Golda Damari from the Department of Veterinary Resources for their invaluable assistance in generation and maintenance of mice.

The authors declare no competing financial interests.

Correspondence should be addressed to Dr. Elior Peles, Department of Molecular Cell Biology, Weizmann Institute of Science, 234 Herzl Street, Rehovot 76100, Israel. E-mail: peles@weizmann.ac.il.

DOI:10.1523/JNEUROSCI.0571-13.2013

Copyright $\odot 2013$ the authors $\quad 0270-6474 / 13 / 3310950-12 \$ 15.00 / 0$ al., 2010), between the external layer and the surrounding basal lamina (Court et al., 2006), or between the internal Schwann cell membrane and the axon (Pedraza et al., 1990; Einheber et al., 1997; Poliak et al., 1999; Tait et al., 2000; Eshed et al., 2005; Maurel et al., 2007; Spiegel et al., 2007). At the axon-glial interface, CAMs are thought to regulate cell recognition and functional organization of the axolemma into distinct domains, which are essential for saltatory conduction (Poliak and Peles, 2003; Susuki and Rasband, 2008).

Cell adhesion molecule 4 (Cadm4; also known as SynCAM4 or Necl4) mediates Schwann cell-axon interaction (Maurel et al., 2007; Spiegel et al., 2007). Cadm4 belongs to a distinct family of CAMs (Cadm1-Cadm4), which mediate specific cell-cell contact through homophilic and heterophilic interactions (Biederer, 2006; Takai et al., 2008). In the peripheral nervous system (PNS), Cadm proteins are differentially expressed in Schwann cells and axons; Cadm1, Cadm2, and Cadm3 are found in axons, whereas Cadm4 and Cadm2 are present in myelinating Schwann cells (Maurel et al., 2007; Pellissier et al., 2007; Spiegel et al., 2007). Axon-glia interaction is primarily mediated by binding of glial Cadm4 to axonal Cadm3 and Cadm2 (Maurel et al., 2007; Spiegel et al., 2007). Disruption of this interaction by the addition of a soluble extracellular domain of Cadm 4 to myelinating cultures markedly reduced the number of myelin segments (Spiegel et al., 2007). Similarly, expression of a dominant mutant form of Cadm4 in Schwann cells (Spiegel et al., 2007), or knockdown of Cadm4 by shRNA (Maurel et al., 2007), led to reduced myelination, further suggesting that Cadms play a critical role in myelination. Genetic inactivation of $\mathrm{Cadm} 3$ in mice delays myelination in the CNS but does not affect the PNS (Park et al., 
A

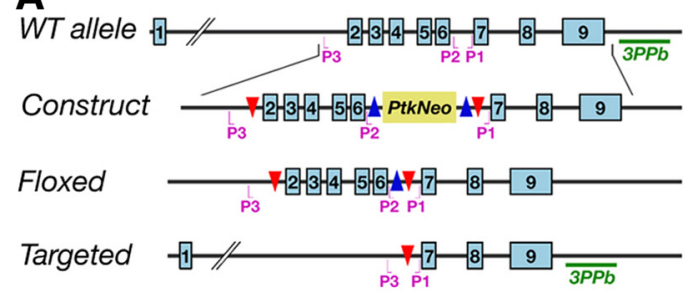

$\mathbf{F}$
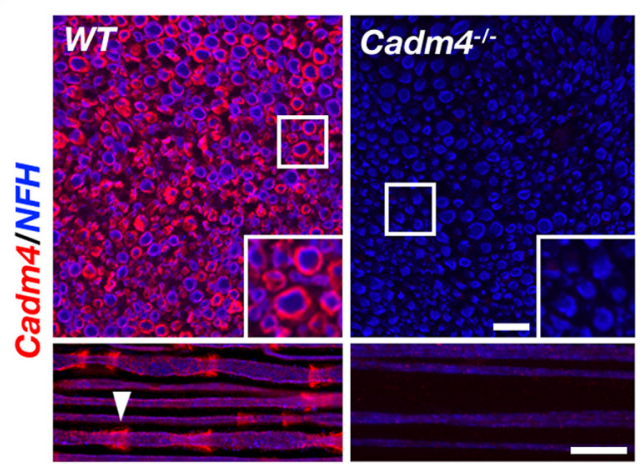

$\mathbf{J}$
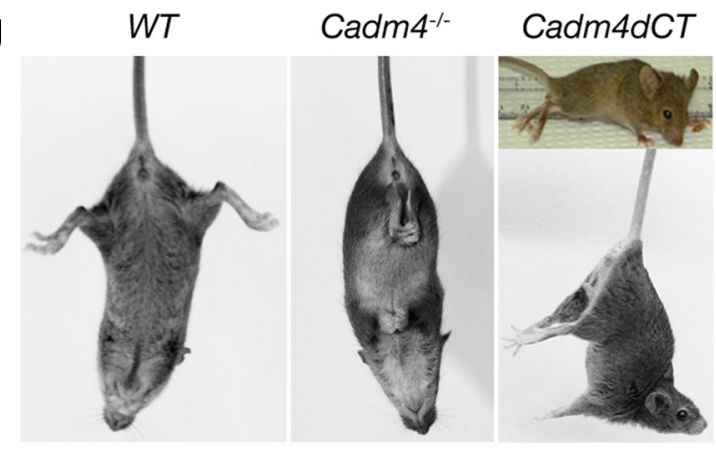

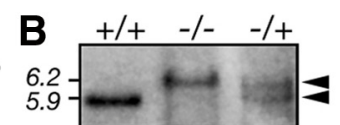

C

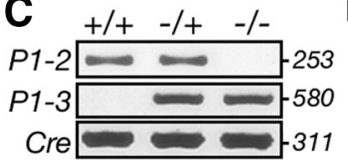

D

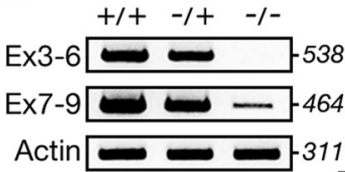

G

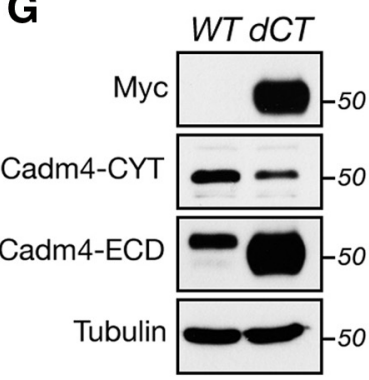

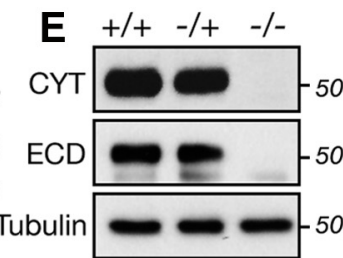

\section{H Cadm4dCT}

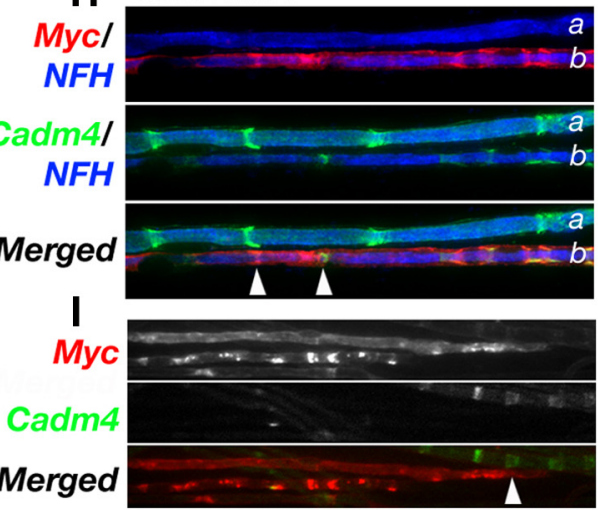

Merged

L
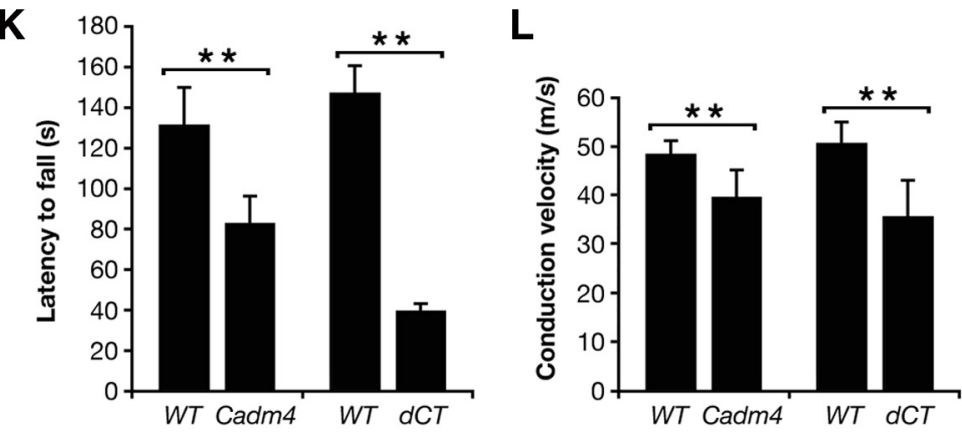

Figure 1. Absence of Cadm4, or transgenic expression of a Cadm4 mutant lacking its cytoplasmic domain, results in motor abnormalities. $\boldsymbol{A}$, Schematic representation of the targeting vector (construct), genomic Cadm4, floxed, and mutant loci. Exons (blue boxes), loxP sites (red triangles), FRT sites (blue triangles), and primers used for genotyping (P1-P3) are indicated. B, Southern blot analysis of genomic DNA of WT $(+/+)$, heterozygous $(-/+)$, or null $(-/-)$ mice using the 3 PPb probe. Molecular mass markers given in $\mathrm{kb}$. $C$, PCR analysis of genomic tail DNA of the indicated genotypes detecting the WT and targeted Cadm4 alleles, and the Cre gene. D, RT-PCR analysis of sciatic nerve mRNA using primer pairs present in exons 3-6 (Ex3-6) and 7-9 (Ex7-9) revealed the absence of a complete Cadm 4 transcript in homozygous mice. Primers for actin were used as controls. C, D, Size markers given in bp. $\boldsymbol{E}$, Western blot analysis of sciatic nerves of the indicated genotypes using antibodies that recognize the cytoplasmic (CYT) or extracellular (ECD) domains of Cadm4, or tubulin as control. No signal is detected in homozygous mice. Molecular mass markers indicated in kDa. $\boldsymbol{F}$, Cadm 4 is undetectable in sciatic nerves of Cadm $4^{-1-}$-null. Cross sections (top) or teased sciatic nerves (bottom) isolated from the indicated genotypes at 2 months of age, immunolabeled using antibodies to Cadm4 and neurofilament (NFH). Insets, Higher magnification of the boxed area. Arrowhead indicates the concentration of Cadm4 in Schmidt-Lanterman incisures. Scale bars, $10 \mu \mathrm{m}$. G, Transgenic expression of a deletion variant of Cadm4 in Schwann cells. Western blot analysis of sciatic nerves isolated from WT or transgenic mice expressing a myc-tagged Cadm4 lacking its cytoplasmic domain under the control of an MBP promoter Tg(mbp-Cadm4dCT). The cytoplasmic Cadm4 antibody (Cadm4-CYT) only recognizes the endogenous protein, whereas the extracellular antibody (Cadm4-ECD) detects both endogenous and transgenic proteins. Tubulin was used as a loading control. There is moderate reduction in endogenous Cadm4 in the transgene. Molecular mass markers indicated in $\mathrm{kDa}$. $\mathrm{H}, \mathrm{I}, \mathrm{Imm}$ monolabeling of teased sciatic nerves isolated from $\mathrm{Tg}(\mathrm{mbp}$-Cadm4dCT) using antibodies to myc-tag (Myc), neurofilament (NFH), and Cadm4 (H), or myc-tag and Cadm4 (I). Merged images are shown at the bottom. $\boldsymbol{H}$, Two myelinated axons that either lack (a) or express (b) the transgene. The presence of the transgene changes the distribution of the endogenous $(\mathrm{adm} 4$ ( $\boldsymbol{H}$, arrowheads). $\boldsymbol{I}$, Although endogenous Cadm4 is only weakly detected in myelin units overexpressing the transgene, it is normally present in myelinating Schwann cells lacking it (arrowhead). Scale bars, $10 \mu \mathrm{m}$. J, Cadm $4^{-1-}$ and $\mathrm{Tg}(\mathrm{mbp}$-Cadm4dCT) mice exhibit abnormal clasping of their hindlimbs when suspended by their tail. $\mathrm{Tg}\left(m b p\right.$-Cadm4dCT) animals also developed hindlimb paralysis (top). $\boldsymbol{K}$, Analysis of motor performance by rotarod. Adult Cadm4 ${ }^{-/-}$(Cadm4) and $\operatorname{Tg}(\mathrm{mbp}$-Cadm4dCT) mice exhibit a shorter latency to fall compared with their littermate controls. Error bars indicate $S D$ of $n>8$ mice per genotype. ${ }^{* *} p<0.001$. L, Compound action potentials recorded from adult mice show a reduction in nerve conduction velocity in both mutants. Error bars indicate SD of $n>6$ mice per genotype. ${ }^{* *} p<0.001$.

2008). In the present study, we set to examine the role of Cadm proteins in myelination in vivo by generating mice that lack each member of this family. Our results suggest that Cadm4 plays an essential role not only in mediating Schwann cell-axon contact, but also in myelin membrane growth in the PNS.

\section{Materials and Methods}

Generation of mutant mice. Cadm2 (SynCAM2/Necl3), Cadm3 (SynCAM3/Necl1), and Cadm4 (SynCAM4/Necl4) mutant mice were generated by a standard gene targeting approach, using targeting vectors containing a Neomycin (Neo) resistance gene flanked by two FRT sites and two loxP sites that flank exon1 in Cadm2 and Cadm3, or exons 2-6 in Cadm4. Chimeric mice were bred with SvEv129 mice. Targeted mice were crossed with FLP deleter mice (Farley et al., 2000) to remove the Neo cassette, leaving the targeted Cadm exons floxed by a pair of loxP sites. Deletion of the floxed region was achieved by further crossing to either PGK-Cre (Lallemand et al., 1998) or Dhh-Cre (Jaegle et al., 2003) mice. Southern blot analysis was done as described previously (Feinberg et al., 2010). Genotyping was done by PCR of genomic DNA using the following primer: Cadm 1 WT allele, GATGTGTGCTGACTTAGGAACG GTC and GAGTGATTAACAACGTGCAGGCAAT; targeted, GATGTG TGCTGACTTAGGAACGGTCandTGCGAGGCCAGAGGCCACTTGT 
GTAGC; Cadm2 WT allele, AGGCACAAGT TGCCAGCCA and ATTCCACCCCGTATTT CCA; targeted, AGGCACAAGTTGCCAGCCA and CAAGTTAGCACGTGGCCACC; Cadm3 WT allele, GCCCTGACTGAAACAGCGAC and CAGGGAGCCTGTTGGCTTTG; targeted,GCCCTGACTGAAACAGCGACandCT TTGCTCCACACCCGAGTG; Cadm4 WT allele, CGCAGTTCTGATCCAGCATC and AT CAGAGGACAGCTCATGAG; targeted,CGCA GTTCTGATCCAGCATC and GGCAGGAG GGTTGCCATGA. The generation of Cadm 1 mutant mice was previously described (Fujita et al., 2005).

RNA analysis. Total RNA was isolated from freshly dissected tissues using either TRI-reagent (Sigma-Aldrich) or RNeasy micro kit (QIAGEN), cDNAs were obtained with SuperScript-II reverse transcriptase (Invitrogen) using oligo-dT. Specific PCR primer sets were designed according to mRNA sequences (GenBank database). PCR amplification product levels were normalized among samples with actin-specific primers. The following primer pairs were used for mRNAbased RT-PCR analysis: Cadm1 (exons 1-3), CA CTGATCCCCACAGGTGA and CAGCTGAC TGGTCACAGTGT; Cadm2 (exons 1-3), CGGT TCTCCGCTTCTACAG and CAGGACA GTGAGATAGGCC; Cadm3 (exons 1-5), CACT GATCCCCACAGGTGA and GAGCTGCTCA CAGTGAAGG; Cadm4 (exons 2-4), GACGGG ACAGGAAGTACAG and GTCCGAGAGCAAG CAGTG; Cadm4 (exons 3-6), CTCTGAAGGA CGAGCGATTC and GTTCCCTGTGACAGCA CAG; Cadm4 (exons 7-9), CAGAGACTCATT CCCACG and CGTGGGAATGAGTCTCTGC; actin GAGCACCCTGTGCTGCTCACCGAGG and GTGGTGGTGAAGCTGTAGCCACGCT.

Electrophysiology and motor function. Sciatic nerve conduction velocity measurements were performed on adult animals of each genotype $(n>5)$ essentially as described previously (Feinberg et al., 2010). Rotarod and tail suspension tests were performed as described previously (Novak et al., 2011).

Antibodies. A purified rabbit antibody to Cadm4 was prepared by preabsorbing polyclonal rabbit anti-Cadm4 serum (Spiegel et al., 2007) on a GST column, followed by a second preabsorption on GST-Cadm1. The following primary antibodies were used as well: mouse anti-Necl4ECD (NeuroMab), rat anti-MBP (Millipore Bioscience Research Reagents), rat and mouse antineurofilament (Millipore Bioscience Research Reagents), rabbit and mouse anti-Caspr (Peles et al., 1997; Gollan et al., 2002), Chick anti-P0 (Aves), mouse anti-tubulin (Santa Cruz Biotechnology), mouse anti-MAG (EMD Millipore), mouse antibody to Kv1.2 (K14/16) (NeuroMab), rat anti-NrCAM (Lustig et al., 2001), and mouse anti-pan sodium channels (Sigma-Aldrich). Fluorophore-coupled antibodies included the following: 488coupled anti-rabbit was purchased from Invitrogen; Cy3-coupled antirabbit, Cy3-coupled anti-mouse, and Cy5-coupled anti-rat were obtained from Jackson ImmunoResearch Laboratories.

Immunolabeling and Western blot analysis. Sciatic nerves were teased and immunolabeled as previously described (Spiegel et al., 2007). For paraffin embedding, sciatic nerves were dissected, rinsed with PBS, and fixed for $48 \mathrm{~h}$ in Bouins buffer (Sigma-Aldrich). Tissues were then embedded in paraffin, sectioned, and mounted on glass slides. Antigen retrieval was done in boiling $0.01 \mathrm{~m}$ sodium citrate buffer ( $\mathrm{pH}$ 6). Images were ac-
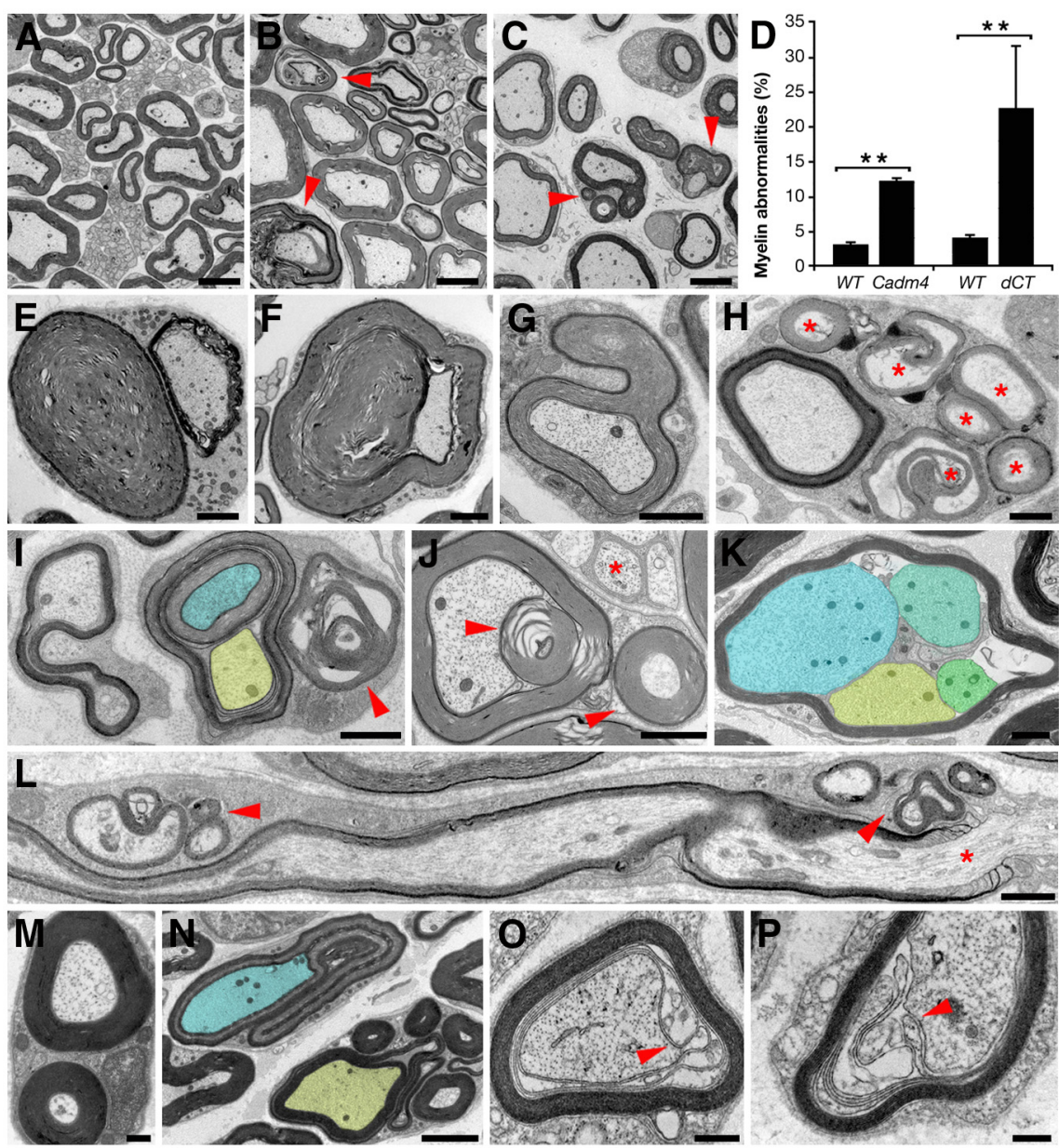

Figure 2. Cadm $4^{-/-}$and Cadm4dCT mice exhibit peripheral myelin abnormalities. $\boldsymbol{A}-\boldsymbol{C}$, Low-magnification EM images of sciatic nerves sections obtained from P30 WT $(\boldsymbol{A})$, $C a d m 4^{-1-}(\boldsymbol{B})$, or $\operatorname{Tg}(\mathrm{mbp}$-Cadm4dCT) $(\boldsymbol{C})$ mice. Misfolded and degenerated myelinated axons counted. Data represent the mean \pm SEM for 600 myelinated fibers from each group ( $n=3$ per genotype). ${ }^{* *} p<0.0001 . \boldsymbol{E}, \boldsymbol{F}$, EM images of sciatic nerves cross sections of P60 Cadm4-null mice showing tomacula. Axonal displacement from focal hypermyelination shown in $\boldsymbol{F}$. $\boldsymbol{G}$, Comma-shaped outfolding is already detected at P7 in the mutant. $\boldsymbol{H}$ Recurrent loops and bizarre myelin outfoldings ( ${ }^{*}$ ) are detected in cross sections of Cadm4-null nerves. I, At P3, Cadm4 mutants show various myelin misfoldings, such as comma-shaped outfoldings (left) and complex myelin tomacula involving multiple axons Schwann cell cytoplasm, and between the axon and the main myelin sheath (arrowheads). Nonmyelinating Schwann cells appear normal (asterisks). $\boldsymbol{K}$, Abnormal configuration of a single Schwann cell that myelinates multiple axons (colored). $\boldsymbol{L}$, Longitudinal and above the paranodes (asterisks). $\boldsymbol{M - P}$, Multiple abnormal myelin configurations are detected in $\operatorname{Tg}(\mathrm{mbp}$-Cadm4dCT) nerves at (colored). The cell on the left is in the process of forming a tomaculum, whereas the one on the right produces myelin profiles that are covered by its plasma membrane. $\mathbf{0}, \boldsymbol{P}$, Detachment of the myelin sheath from the axon (arrowhead). There is presence of multiple inner lips. Scale bars, $1 \mu \mathrm{m}$.

quired using a Hamamatsu ORCA-ER CCD camera, controlled by Axiovision 4.7 acquisition software (Carl Zeiss). Processing of images was done using Photoshop CS3 software (Adobe). Quantification of the myelin segments was performed using Volocity 4.2.1 image analysis software (Improvision). For Western blot analysis, sciatic nerves were dissected, snap frozen in liquid nitrogen, and extracted in Laemmli sample buffer. Spinal cord samples were lysed in RIPA buffer (50 mm Tris-HCl, pH 7.4, 1\% NP-40, $0.25 \%$ sodium deoxycholate, $150 \mathrm{~mm} \mathrm{NaCl}, 1 \mathrm{~mm}$ EDTA, 1:100 protease inhibitor mixture, Sigma-Aldrich).

Electron microscopy. Sciatic nerves were fixed with Karnovsky fixative (2.5\% glutaraldehyde, 4\% PFA, 3\% sucrose, in $0.1 \mathrm{M}$ cacodylate buffer) and further processed as previously described (Feinberg et al., 2010; Novak et al., 2011). Samples were examined using a transmission electron microscope (CM-12; FEI) equipped with a camera (Eagle $2 \mathrm{~K}^{\circ}-2 \mathrm{~K}$; FEI). 
A

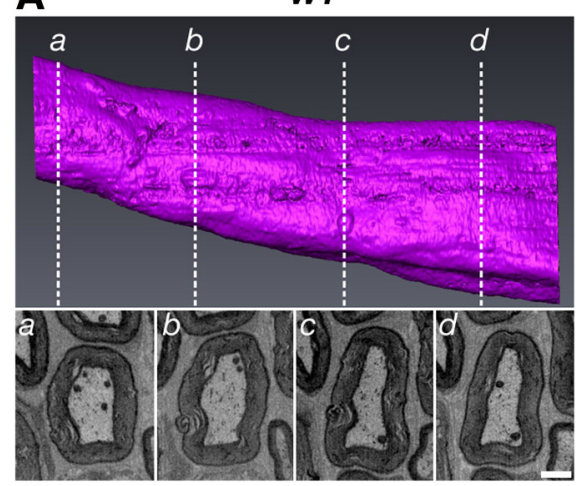

C

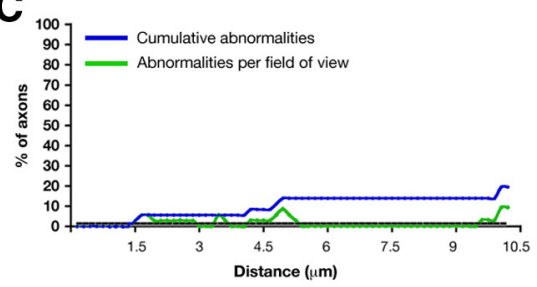

B Tg(mbp-Cadm4dCT)

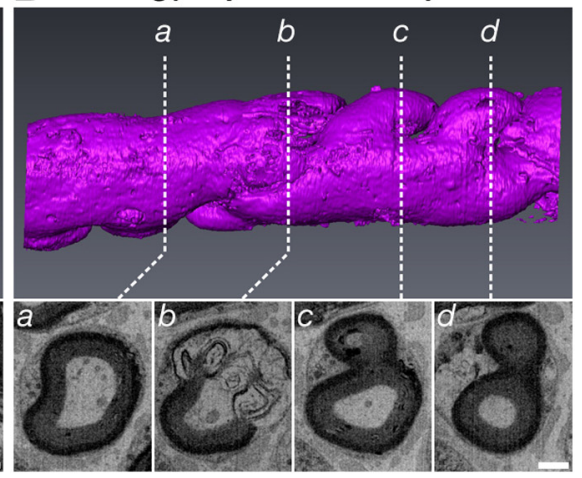

D

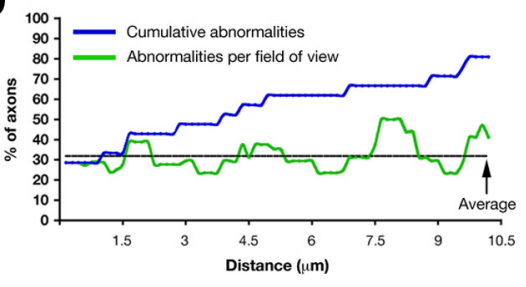

Figure 3. Heterogeneous distribution of myelin abnormalities along the length of the internodes. Serial FIB/SEM images (700 total, $15 \mathrm{~nm}$ apart) were generated from WT or $\operatorname{Tg}(\mathrm{mbp}$-Cadm4dCT) sciatic nerves. $\boldsymbol{A}, \boldsymbol{B}, 3 \mathrm{D}$ rendering of an individual myelinated WT or $\operatorname{Tg}(m b p-C a d m 4 d C T)$ axon. Single sections taken from different positions along the axon (a-d) are shown below. Scale bars, $5 \mu \mathrm{m}$. C, D, The number of myelin abnormalities counted every $150 \mathrm{~nm}$ is shown as a percentage of the total number of myelin profiles in each section (green line), or as the cumulative percentage of affected axons along the longitudinal nerve axis (blue line; i.e., representing the total number of different abnormal axons; each affected axon was counted only once along the stack).

Semithin sections $(1.5 \mu \mathrm{m})$ were stained with toluidine blue and analyzed under a light microscope (Nikon Eclipse E800). Threedimensional reconstruction was prepared using focused ion beam/ scanning electron microscope (FIB/SEM) (dual-beam Helios 600 system-FEI).

Quantitation and statistical analysis. The number of normal and abnormal myelin profiles (see Fig. 2) was determined by counting $>1200$ fibers from 3 or 4 mice of each genotype (3-4 weeks of age). The percentage of myelin profiles at different developmental ages (see Fig. 4) was determined by counting $>700$ fibers from 3 mice of each genotype. Percentage of abnormal paranodes was calculated from 200 nodal regions in 3 mice (P60) of each genotype. In experiments in which multiple samples were compared, the statistical significance was determined using the two-tailed $t$ test according to the Bonferroni correction. Myelinated axons g-ratio (myelin radius/myelinated axon radius) was calculated from $>300$ profiles in representative fields (mice 1-2 months of age; $n=$ 3 or 4$)$.

\section{Results}

Cadm4 null and transgenic Cadm4dCT mice exhibit impaired motor function

To study the role of Cadm4 in myelination in vivo, we generated a conditional floxed allele of the gene that carries two loxP sites flanking exons 2-6 ( Cadm $4^{f l f l}$; Fig. $\left.1 A\right)$. Removal of these exons was achieved by crossing Cadm $4^{f l f l}$ mice with a PGK-Cre line (Lallemand et al., 1998). Genotyping of PGK-Cre/Cadm $4^{f l f l}$ (referred to here as $\mathrm{Cadm} 4^{-/-}$mice) was determined by Southern blot and PCR analysis of tail DNA (Fig. $1 B, C$ ). RT-PCR analysis performed on mRNA from sciatic nerves of control, heterozygous, and homozygous mutant mice using primers located within exons 3-6 showed a complete absence of Cadm4 transcript (Fig. 1D). Similar analysis using primers located in exons 7-9 revealed that a truncated Cadm4 transcript was weakly present in the mutant (Fig. 1D). Nevertheless, as revealed by Western blot analysis using two distinct antibodies directed against the cytoplasmic or the amino-terminal end of the protein, Cadm4 was completely absent in sciatic nerves of homozygous animals (Fig. 1E). Similarly, no specific signal was detected by immunolabeling of sciatic nerve cross sections (Fig. $1 F$, top), and teased fiber preparations, with an antibody to Cadm4 (Fig. $1 F$, bottom), further indicating that Cadm $4^{-/-}$is a complete null. As an additional approach to study the role Cadm4 plays in myelination, we generated transgenic mice expressing a myc-tagged deletion mutant of Cadm4 lacking its entire cytoplasmic domain (Cadm4dCT) under the MBP promoter (Farhadi et al., 2003). Western blot analysis showed a strong expression of Cadm4dCT in $\operatorname{Tg}(m b p-$ Cadm4dCT) mice but not in WT animals (Fig. $1 G$ ). Blotting with an antibody directed to the cytoplasmic domain of Cadm4 (which only detects the endogenous protein) revealed that the expression of the transgene resulted in a decreased amount of the endogenous protein (Fig. $1 G)$. This conclusion was further supported by immunolabeling of transgenic sciatic nerve using antibodies to myc and Cadm4, showing a dramatic reduction in the expression of the endogenous Cadm 4 in fibers expressing high levels of Cadm4dCT (Fig. 1H). Cadm4dCT was distributed along regions of noncompact myelin, where it was occasionally found in aggregates, alone or together with the endogenous Cadm4 (Fig. 1I).

Homozygous Cadm4 $4^{-/-}$mice exhibited hind leg rigidity during their first 3 weeks of life. When suspended by their tail, they displayed spastic leg extension and an enhanced clasping reflex (Fig. 1J). These abnormalities were more pronounced in $\operatorname{Tg}(m b p-C a d m 4 d C T)$ mice, which also developed hindlimb paralysis (Fig. $1 J)$. Cadm $4^{-/-}$and $\operatorname{Tg}(m b p$-Cadm4dCT) mice tended to stagger and fell more rapidly from a rotarod compared with WT littermates, further indicating that either the absence of Cadm4, or its abnormal expression in Schwann cells, resulted in a motor coordination defect (Fig. $1 K$ ). Akin to their motor deficits, both mutants exhibit a moderate but significant decrease in nerve conduction velocity (Fig. $1 L$ ).

\section{$\mathrm{Cadm} 4^{-/-}$and $\operatorname{Tg}(m b p-C a d m 4 d C T)$ mice exhibit neuropathy-like focal hypermyelination}

Electron microscopy analysis of sciatic nerves isolated from adult $\mathrm{Cadm} 4^{-1-}$ and $\operatorname{Tg}(m b p-C a d m 4 d C T)$ mice showed that these mutants formed myelin with thickness comparable with that of age-matched wild-type mice (Fig. 2A-C; average g-ratios: $\mathrm{Cadm} 4^{-1-} 0.61 \pm 0.02$ vs $0.63 \pm 0.01$ of littermate control; $\operatorname{Tg}(m b p-C a d m 4 d C T) 0.68 \pm 0.03$ vs $0.67 \pm 0.02$ of littermate control). However, in contrast to WT nerves, myelinated axons in $C a d m 4^{-/-}$and $\operatorname{Tg}(m b p-C a d m 4 d C T)$ displayed a range of myelin abnormalities, including tomacula (Fig. 2E,F), commashaped myelin outfolds (Fig. 2G,I), and redundant myelin profiles (Fig. $2 H, I, M, N$ ). These abnormalities were more frequent in $\operatorname{Tg}(\mathrm{mbp}-\mathrm{Cadm} 4 \mathrm{dCT})$ than in $\mathrm{Cadm} 4^{-/-}$mutant mice. In some instances, the appearance of tomacula was accompanied with degeneration of the myelin around the axon (Fig. $2 E$ ), and axonal displacement (Fig. 2F). The redundant myelin outfoldings were present within the Schwann cell cytoplasm, as well as 
A

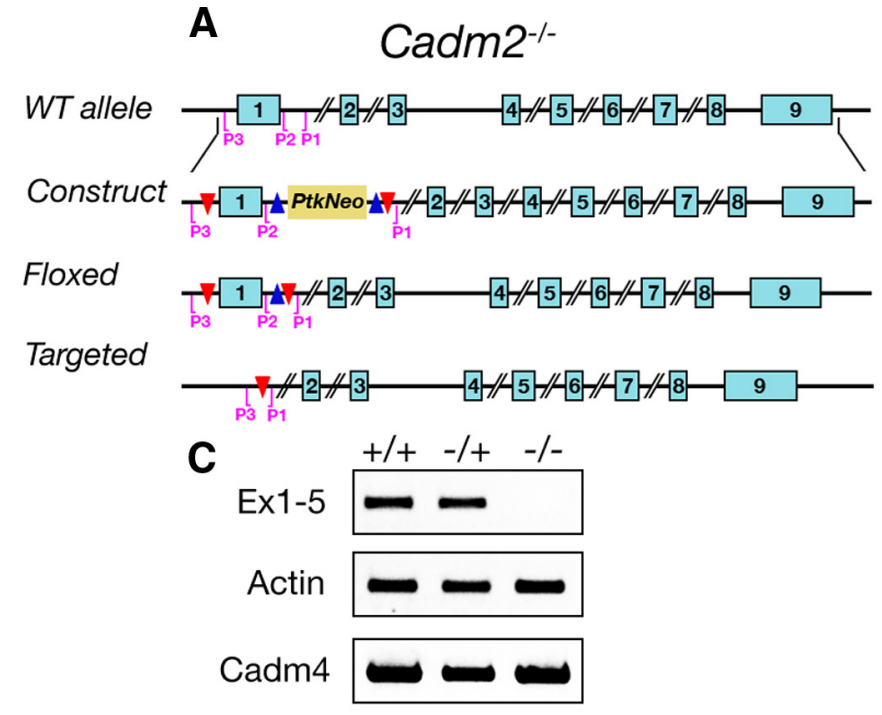

B

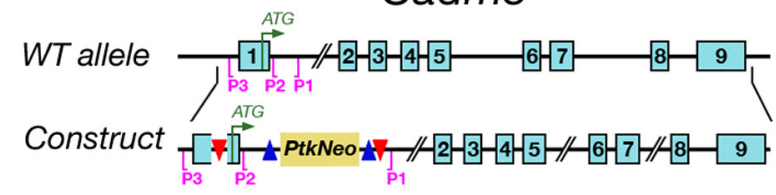

Floxed

Targeted

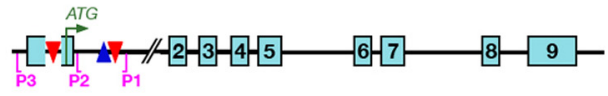

D
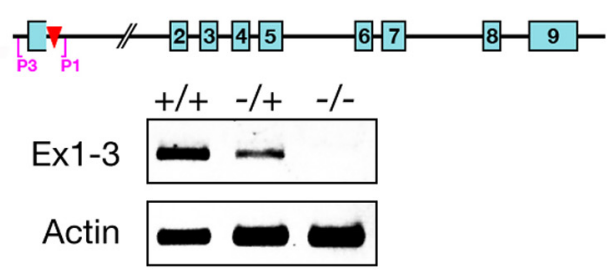

Cadm4

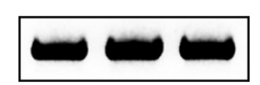

Cadm2 $2^{-1-}$ Cadm3 $3^{-1-}$
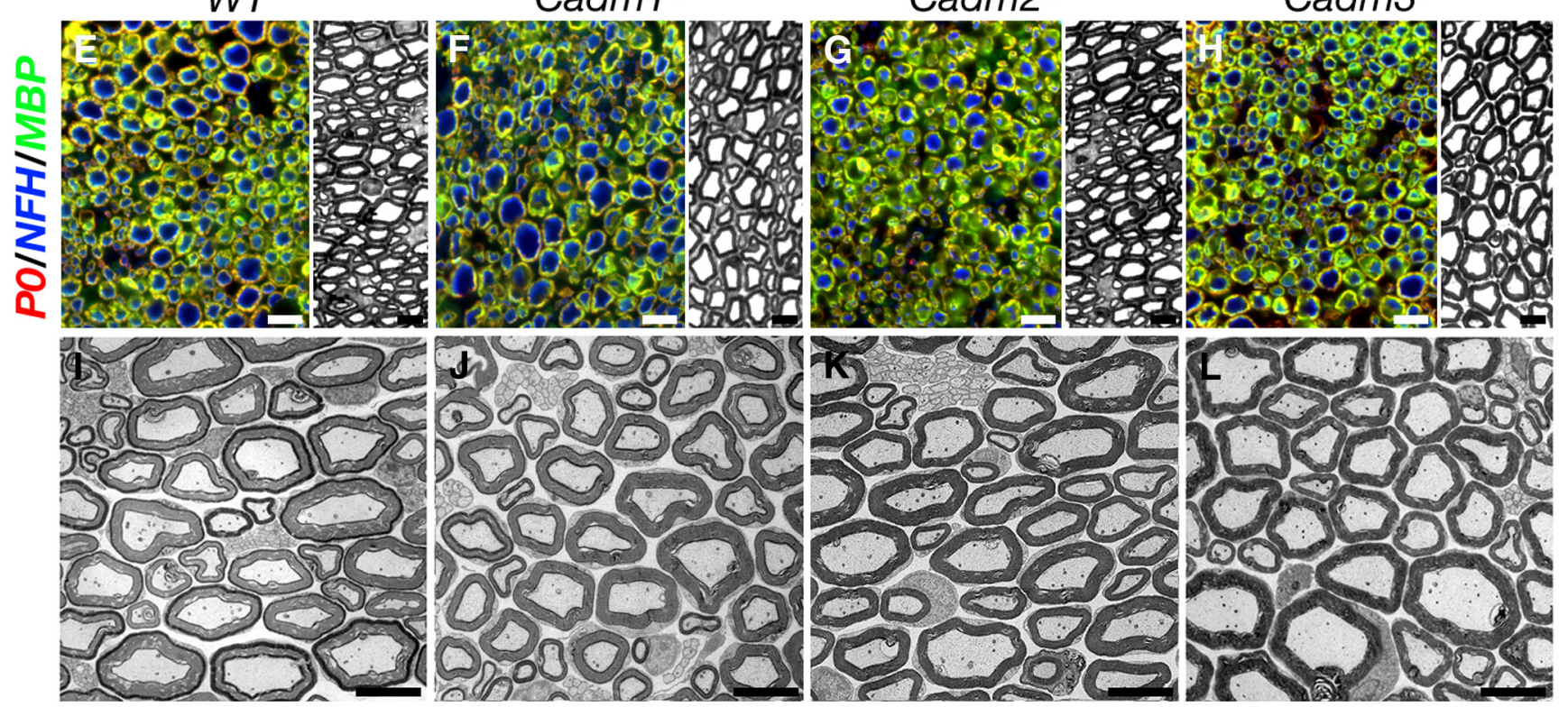

Figure 4. Absence of myelin abnormalities in $\mathrm{Cadm} 1^{-/-}$, $\mathrm{Cadm}^{-/-}$, or Cadm $3^{-/-}$mice. $\boldsymbol{A}, \boldsymbol{B}$, Schematic representation of the genomic Cadm2 ( $\left.\boldsymbol{A}\right)$ or $\mathrm{Cadm} 3(\boldsymbol{B})$ loci, and the targeting vectors (construct) used, as well as the floxed, and mutant alleles. The location of exons (numbered in blue boxes), loxP sites (red triangles), FRT sites (blue triangles), and primers used for genotyping (P1-P3) are indicated. C, D, RT-PCR analysis of sciatic nerve mRNA using the indicated primer pairs revealed the complete absence of Cadm2 (C) and Cadm3 (D) transcripts in Cadm2 and Cadm3 homozygous mice, respectively. Primers for actin and Cadm 4 were used as controls. E-H, Immunolabeling of sciatic nerve cross sections of WT mice, Cadm $1\left(\mathrm{Cadm}^{-1-}\right)$, Cadm2 (Cadm2 $\left.{ }^{-1-}\right)$, or Cadm3 $\left(\mathrm{Cadm}^{-/-}\right)$-null mice, using antibodies to P0, neurofilament (NFH), and MBP. Corresponding toluidine blue-stained semithin sections of sciatic nerves are shown in the insets on the right of each panel. $\boldsymbol{I}-\boldsymbol{L}$, Low-magnification EM images of sciatic nerve cross sections obtained from P60 control (I), or Cadm 1 (J), Cadm2 (K), and Cadm3 ( $\boldsymbol{L}$ ) null mice, showing normal myelin. Scale bars: $E-H, 10 \mu \mathrm{m} ; \boldsymbol{I}-\mathbf{L}, 1 \mu \mathrm{m}$.

between the myelin sheath and the axon (Fig. 2J). In longitudinal sections (Fig. 2L), redundant myelin profiles were detected near paranodes and Schmidt-Lanterman incisures, in agreement with previous studies, suggesting that myelin outfolds originate from areas of noncompact myelin (Bolino et al., 2004; Bonneick et al., 2005; Tersar et al., 2007; Goebbels et al., 2012; Horn et al., 2012). In 2-week-old transgenic mice, we also noted a detachment of the myelin sheath from the axon at the inner mesaxon, and the presence of multiple inner myelin lips, which reflect aberrant continuation of the myelination process (Fig. 2O,P). Quantitation of the number of myelin abnormalities using conventional transmission EM revealed that they ranged from $12.2 \%$ in $\mathrm{Cadm} 4^{-1-}$ to $22.4 \%$ in $\operatorname{Tg}(\mathrm{mbp}$ Cadm4dCT) (Fig. 2D). To further evaluate the extent of my- elin abnormalities, we used serial section images of FIB/SEM (Knott et al., 2008) to follow individual axons (Fig. 3). We either counted the number of myelin abnormalities in each section (abnormalities per field of view in Fig. $3 C, D$ ), as a well as the number of different axons that show at least one myelin abnormality along their longitudinal axis (cumulative abnormalities; each affected axon was counted only once). As depicted in Figure $3 D$, we found that $81 \%$ of all myelinated axons of the $\operatorname{Tg}(m b p-$ Cadm4dCT) mutant will exhibit focal sites of hypermyelination at least once along their longitudinal axis. This result supports previous studies, suggesting that the number of myelin outfolds detected in cross sections of other tomacula neuropathy models represents an underestimate of the number of affected axons (Stendel et al., 2007; Goebbels et al., 2012). 

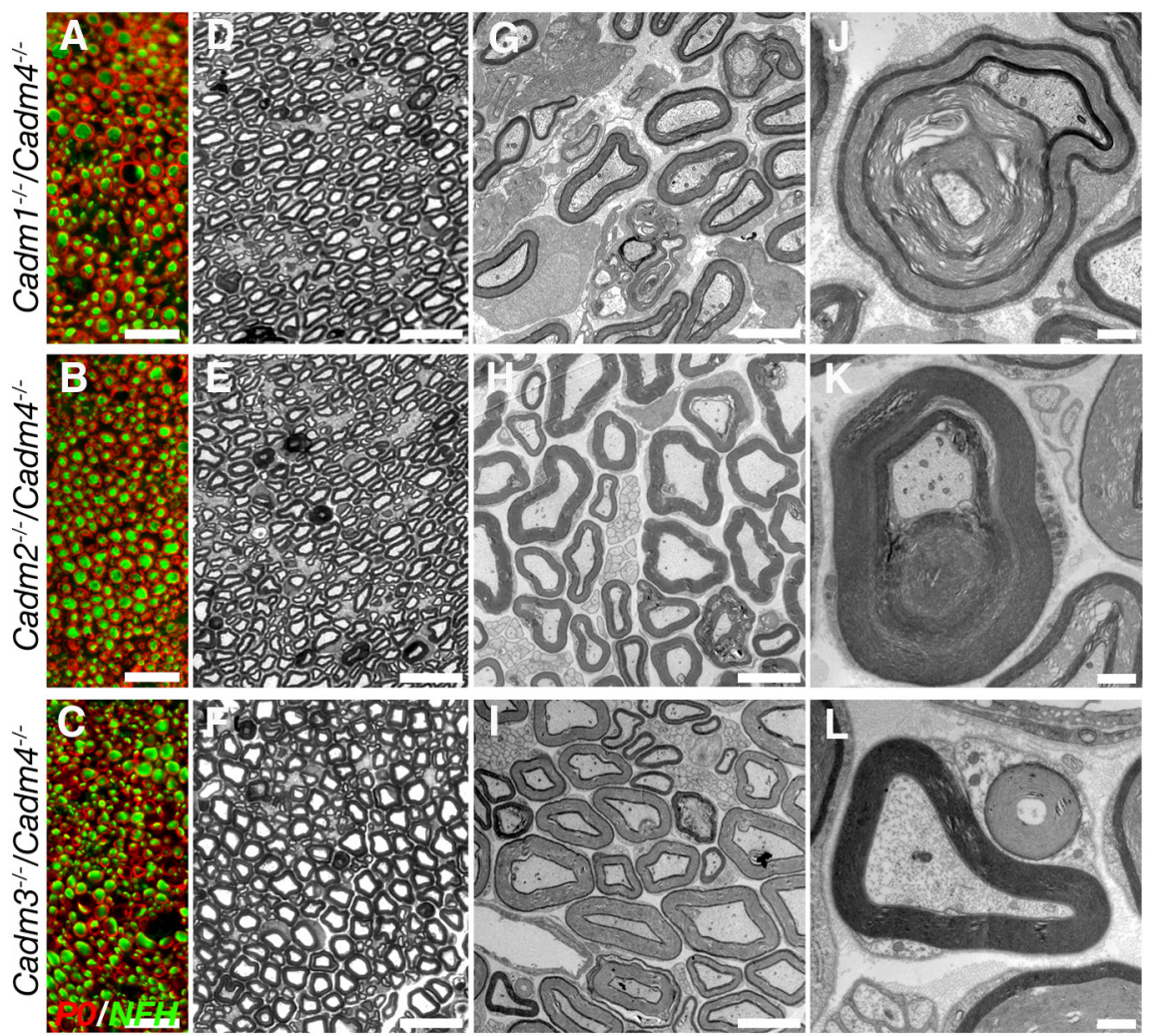

Figure 5. Deletion of Cadm4 together with Cadm 1, Cadm2, or Cadm3 does not exacerbate the myelin phenotype of Cadm $4^{-1}$ mice. A-C, Immunolabeling of sciatic nerve cross sections of mice lacking Cadm1 and Cadm4 (Cadm $\left.{ }^{-/-} / \mathrm{Cadm}^{-/-}\right)$, Cadm2 and Cadm4 (Cadm2 ${ }^{-1-} / \mathrm{Cadm}^{-1-}$ ), or Cadm3 and Cadm4 (Cadm3 $\left.{ }^{-1-} / \mathrm{Cadm}^{-1-}\right)$ using antibodies to P0 and neurofilament (NFH). $\mathbf{D}-\boldsymbol{F}$, Toluidine blue-stained semithin cross sections of sciatic nerves isolated from the indicated genotypes. $\mathbf{G}-\boldsymbol{I}_{\boldsymbol{i}}$ Low-magnification EM images of sciatic nerve cross sections obtained from the indicated genotypes. $J$ - $L$, Higher-magnification EM images showing similar myelin abnormalities as detected in mice lacking only Cadm4. Scale bars: $\boldsymbol{A}-\boldsymbol{C}, 40 \mu \mathrm{m} ; \mathbf{D}-\boldsymbol{F}, 20 \mu \mathrm{m}$; G-I, $5 \mu \mathrm{m} ; J-L, 2 \mu \mathrm{m}$

\section{Absence of myelin abnormalities in mice lacking Cadm1, Cadm2, or Cadm3}

The close sequence similarity between the four Cadm proteins (Biederer, 2006), along with their overlapping expression (Kakunaga et al., 2005; Maurel et al., 2007; Pellissier et al., 2007; Spiegel et al., 2007) and their ability to interact heterophilically with each other (Biederer, 2006; Takai et al., 2008), prompted us to examine whether other Cadm proteins play a role in PNS myelination. To this end, we used a gene-targeting approach to generate conditional floxed alleles of Cadm 2 and Cadm 3 by flanking their first coding exon with two loxP sites ( $\mathrm{Cadm} 2^{f l / f l}$ and $\mathrm{Cadm} 3^{f l / f l}$; Fig. $4 A, B)$. Removal of these exons was achieved by crossing $C a d m 2^{f l f l}$ and $C a d m 3^{f l f l}$ mice with a PGK-Cre line (i.e., PGK$\mathrm{Cre} / \mathrm{Cadm} 2^{f l / f l}$ and $\mathrm{PGK}-\mathrm{Cre} / \mathrm{Cadm} 3^{f l f l}$, referred to here as $\mathrm{Cadm} 2^{-1-}$ and $\mathrm{Cadm} 3^{-/-}$mice, respectively). RT-PCR analysis of mRNA from sciatic nerves of control, heterozygous, and homozygous Cadm2 and Cadm3 mutant mice demonstrated the complete absence of their corresponding transcripts (Fig. 4C,D). In contrast to $\mathrm{Cadm} 4^{-/-}$mice, homozygous $\mathrm{Cadm} 2^{-/-}$, Cadm3 $3^{-/-}$, or Cadm1 $1^{-/-}$animals (Fujita et al., 2005) showed no neurological abnormalities and were indistinguishable from their WT littermates. Immunolabeling of cross sections of sciatic nerves isolated from WT, Cadm $1^{-1-}, \mathrm{Cadm} 2^{-1-}$, or Cadm3 $3^{-1-}$ mice, using antibodies to $\mathrm{P} 0$, neurofilament (NFH), and MBP, revealed the presence of normal myelin in all genotypes (Fig. $4 E-H)$. The analysis of semithin sections (Fig. $4 E-H$ ), as well of EM micrographs of sciatic nerve cross sections (Fig. 4I-L), re- vealed that, in contrast to $\mathrm{Cadm} 4^{-/-} \mathrm{mu}-$ tants, mice lacking Cadm1, Cadm2, or Cadm3 exhibit normal peripheral myelin. Furthermore, double-mutant mice lacking Cadm4 together with any other Cadm protein, exhibit myelin abnormalities that were comparable with those found in the single Cadm $4^{-/-}$-null (Fig. 5).

\section{Cadm $4^{-l-}$ mice show a delay in the initiation of PNS myelination} Developmental EM analysis of $\mathrm{Cadm} 4^{-1}$ sciatic nerves revealed the appearance of abnormal myelin profiles already during the first postnatal week (Fig. 6). At P1, most of the mutant Schwann cells had already sorted and established a 1:1 relationship with large axons as in WT nerves (Fig. $6 A, E$ ), indicating that Cadm4 is not required for radial axonal sorting. However, in contrast to WT nerves, in which $35.4 \pm 8.4 \%$ of the Schwann cells already form a multilammelar myelin sheath around individual axons, myelin profiles were detected around only $13.8 \pm 1.8 \%$ of the axons in $\mathrm{Cadm} 4^{-1-}$ nerves at P1. At P3, myelination was detected in $43.2 \pm$ $2.1 \%$ of axons compared with $62.4 \pm$ $8.6 \%$ in WT. This significant difference between WT and Cadm4 $4^{-1-}$ mice was observed during the first postnatal days until P5, indicating a developmental delay (Fig. 6B, $C, F, G$ ). We note that myelin thickness in P3 and P5 mutant nerves was similar to wild-type animals (g-ratio: P3 WT $0.771 \pm 0.03, \mathrm{Cadm}^{-/-} 0.774 \pm$ 0.018 and P5 WT $\left.0.7287 \pm 0.03, \mathrm{Cadm}^{-/-} 0.7280 \pm 0.004\right)$. These results indicate that Cadm 4 is required to efficiently execute membrane wrapping, a notion that gains further support from previous findings demonstrating that addition of the extracellular domain of Cadm4 to myelinating cultures affected myelination but not Schwann cell ensheathment (Spiegel et al., 2007).

\section{Absence of Cadm4 results in aberrant axon-glial contact and axonal organization}

The expression and subcellular distribution of Cadm4 in Schwann cells are regulated by protein $4.1 \mathrm{G}$ (Ivanovic et al., 2012) and $\alpha \mathrm{II} / \beta \mathrm{II}$ spectrin (Susuki et al., 2011), suggesting that it may organize membrane contact sites by providing a direct link to the underlying cytoskeleton. In myelinating nerves, axon-glial contact sites organize the axolemma into distinct molecular domains. In WT nerves, $\mathrm{Na}^{+}$channels are concentrated at the nodes of Ranvier and are separated from juxtaparanodal Kv1 channels by the paranodal junction (labeled for Caspr) (Fig. $7 A, C)$. In addition, throughout the internode, Kv1 channels are located in a double strand flanking a single line of Caspr that apposes the inner mesaxon of the myelin sheath (termed juxtamesaxon) (Arroyo et al., 1999). Immunofluorescence analysis of teased sciatic nerves from $\mathrm{Cadm}^{-1-}$ and $\operatorname{Tg}(\mathrm{mbp}$ Cadm4dCT) mice revealed marked abnormalities in both genotypes (Fig. 7B-H): (1) aberrant appearance of Caspr at the paranodes; (2) diffuse Caspr immunoreactivity away from the 

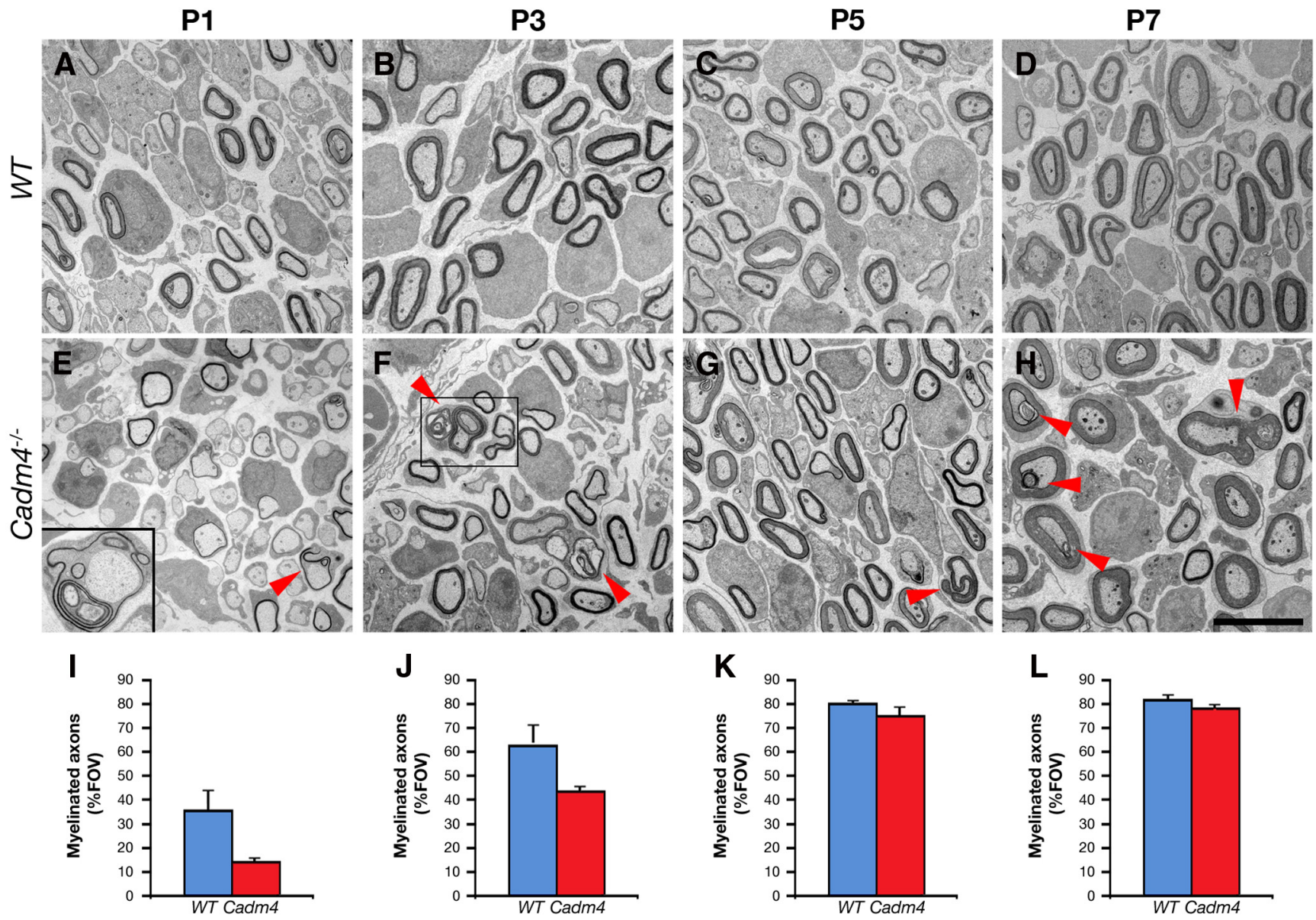

Figure 6. Cadm4-null mice display a delay in the onset of myelination. $\boldsymbol{A}-\boldsymbol{H}$, Low-magnification EM images of sciatic nerve sections from WT $(\boldsymbol{A}-\boldsymbol{D})$ and $C$ adm $4^{-/-}$-null mice $(\boldsymbol{E}-\boldsymbol{H})$ during the first postnatal week. Irregular myelin membrane outgrowth (arrowheads and inset) is already apparent at P1 in the mutant but not in control animals. Higher magnification of the boxed area in $\boldsymbol{F}$ is shown in Figure 2I. I-L, Quantitation of the number of myelinated profiles detected at each postnatal day. Results are shown as a percentage of myelinated axons per field of view (FOV); $n=3$ mice per genotype at different ages $(p<0.001)$. Scale bar, $5 \mu \mathrm{m}$.

paranodes; (3) absence of Caspr and Kv1 channels from the juxtamesaxonal line; and (4) abnormal accumulation of Kv1 channels around the juxtaparanodes, as well as in patches along the internodes (occasionally flanked by Caspr). Quantitative analysis showed that $71 \pm 18 \%$ (250 sites, $n=3)$ of the paranodes in Cadm $4^{-1-}$ displayed abnormal Caspr immunoreactivity, compared with $\pm 2 \%$ (250 sites, $n=3$ ) in WT mice (Fig. 7I). In agreement with these results, EM images of longitudinal sections of sciatic nerves isolated from Cadm $4^{-1-}$ (Fig. $\left.7 J\right)$ and $\mathrm{Tg}(\mathrm{mbp}$ Cadm4dCT) (Fig. 7) mice revealed abnormal splitting of the paranodal loops. These abnormalities were unique to $\mathrm{Cadm} 4^{-\prime-}$ and were not observed in mice lacking the other Cadm genes. To further ascertain that the effect Cadm 4 has on the organization of myelinated axons is the result of its presence in Schwann cells, we eliminated its expression in these cells by crossing $\mathrm{Cadm} 4^{f / f l}$ mice with Desert Hedgehog (DHH)-Cre transgenic mice (DHH-Cre), in which Cre is active in Schwann cell precursor cells (Jaegle et al., 2003). As shown in Figure $8 A-C$, both Cadm4 transcript and protein were undetectable in the sciatic nerve of $\mathrm{DHH}$-Cre/ Cadm $4^{f l / f l}$ mice. These mice also exhibit myelin abnormalities (i.e., tomacula, redundant myelin, and outfolds) comparable with the complete null (Fig. 8D-H). Immunofluorescence analysis of teased sciatic nerves isolated from $\mathrm{DHH}-\mathrm{Cre} / \mathrm{Cadm} 4^{\mathrm{fl} / \mathrm{fl}}$ mice showed severe Caspr abnormalities as in the complete nulls (Fig. $8 I-K$ ). Hence, the presence of Cadm 4 in Schwann cells is essential for the establishment of accurate axon-glial contact sites and the functional organization of myelinated axons.

\section{Discussion}

Our data suggest that Cadm4 plays an essential role in the generation of functional myelinated nerves in the PNS by controlling myelin membrane growth, as well as by mediating an axon-glial contact necessary for the organization of the axolemma. We show that genetic deletion of Cadm 4 or transgenic expression of a truncated Cadm4 in myelinating glia causes a CMT neuropathy-like phenotype characterized by focal hypermyelination (i.e., tomacula, outfolds, and redundant myelin) and disorganization of the axonal membrane. In addition, in young $\mathrm{Tg}(\mathrm{mbp}$ Cadm $4 d C T$ ) nerves, we also detected the presence of multiple inner lips, an abnormal configuration that may indicate that Cadm 4 contributes to the formation of the inner mesaxon (i.e., the contact between the inner Schwann cell lip and the axon). In accordance, we found that, in the absence of Cadm4, Caspr and Kv1 channels disappears from the juxtamesaxonal line. A role for Cadm4 in mediating axon-glia contact is further supported by recent findings showing that ablation of MAG in CMT1A mice (i.e., C22 mice carrying seven copies of the human PMP22 gene) (Huxley et al., 1996), in which Cadm4 expression is markedly reduced, resulted in detachment of the axon from the myelin sheath (Kinter et al., 2012). 

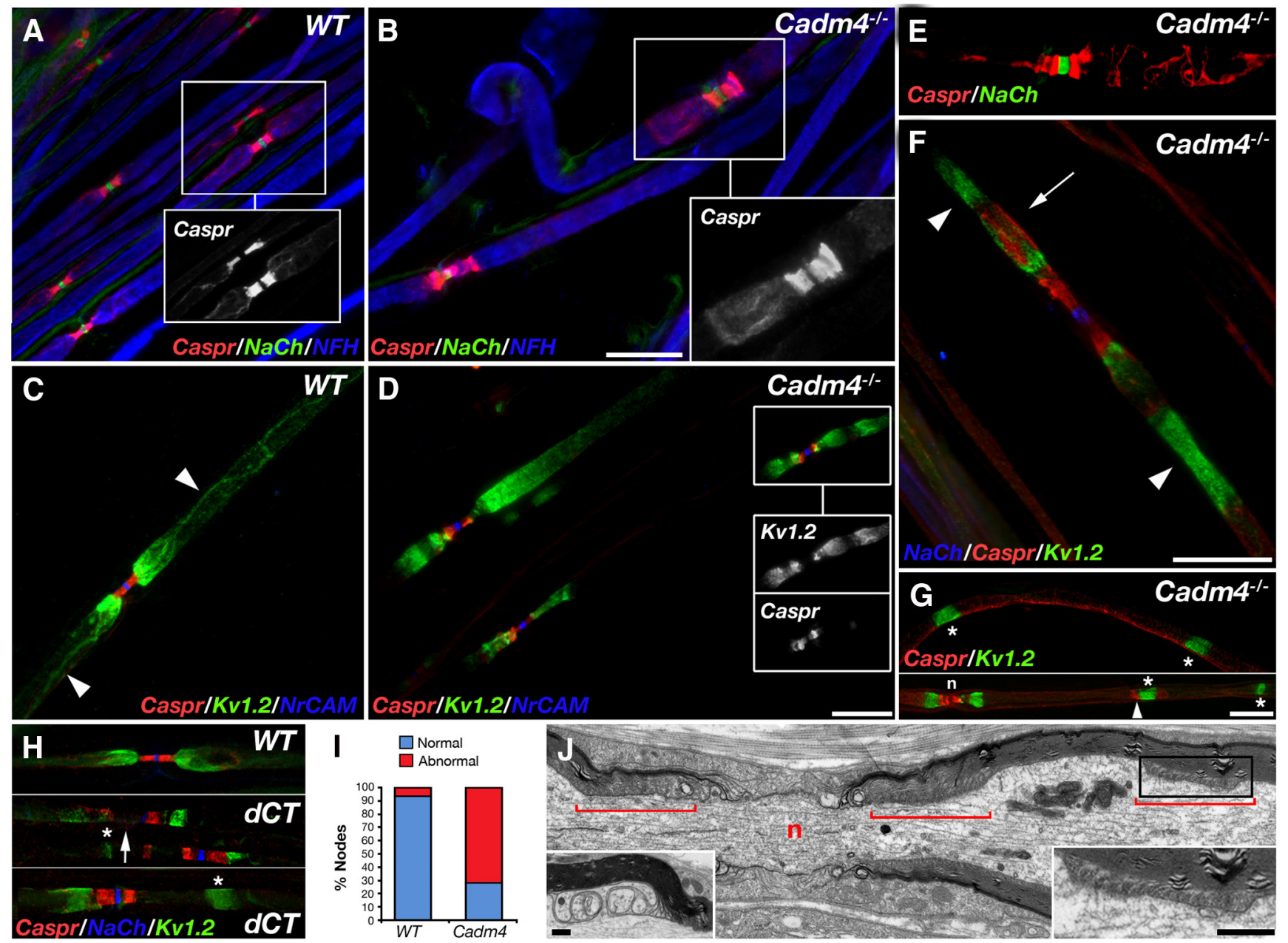

Figure 7. Cadm 4 is required for the molecular organization of the axonal membrane. $A-D$, Triple immunofluorescence labeling of teased sciatic nerves of WT $(A, C)$ and $C a d m 4^{-\prime-}$ mice $(B, D)$, using antibodies to $\mathrm{Caspr}, \mathrm{Na}^{+}$channels $(\mathrm{NaCh})$, and neurofilament (NFH; $\left.\boldsymbol{A}, \boldsymbol{B}\right)$; or to $\mathrm{Caspr}, \mathrm{Kv1.2}$, and $\mathrm{NrCAM}(\boldsymbol{C}, \boldsymbol{D})$. Cadm4-null sciatic nerves show abnormal appearance of Caspr (compare insets in $\boldsymbol{A}$ and $\boldsymbol{B}$ ), and Kv1 channel immunoreactivity was increased at the juxtaparanodes and adjacent area. Both Caspr and Kv1.2 channels are absent from the internodal double mesaxonal line ( $\boldsymbol{C}$, arrowheads). $\boldsymbol{E}$, Labeling of teased sciatic nerves of the mutant with antibodies to Caspr and $\mathrm{NaCh}$. The abnormal distribution of Caspr likely reflects unwinding of the paranodal loops. $\boldsymbol{F}$, Labeling of Cadm4-null sciatic nerves fibers using antibodies to $\mathrm{NaCh}$, Caspr, and Kv1.2. There is aberrant accumulation of Caspr (arrow) and Kv1 channels (arrowheads) away from the NaCh-containing node of Ranvier. G, Cadm4-null nerves exhibit focal accumulations of Kv1 channels along internodes (asterisks), which are occasionally flanked by Caspr immunoreactivity (arrowhead). Location of a node of Ranvier is indicated (n). $\boldsymbol{H}$, Immunolabeling of teased sciatic nerves fibers of the $\mathrm{Tg}(\mathrm{mbp}$-Cadm4dCT) mice show the same abnormalities as in null mice, including internodal accumulation of Kv1 channels (asterisks), and abnormal distribution of Caspr (an arrow in the middle panel marks the absence of (aspr from one side of the node). $I$, Percentage of nodal sites containing either normal or irregular Caspr immunoreactivity in WT and mutant (Cadm4) mice (200 nodes, $n=3$ mice per genotype) $(p<0.005)$. J, Electron micrograph showing a longitudinal section through a node of Ranvier (n) in a Cadm4-null nerve (red lines indicate paranodal junctions). The paranodal junction on the right is split into two distinct areas (right inset, higher magnification of the boxed area). Left inset, Abnormal paranodal processes beneath the compact myelin in $\operatorname{Tg}(m b p$-Cadm4dCT) mice. Scale bars: $\mathbf{A}-\mathbf{C}, 15 \mu \mathrm{m} ; \mathbf{D}-\mathbf{G}, 10 \mu \mathrm{m} ; \boldsymbol{J}, 0.2 \mu \mathrm{m}$.

The absence of Cadm4 in Schwann cells leads to abnormal organization of the underlying axonal membrane. Both Cadm $4^{-1-}$ and $\operatorname{Tg}(\mathrm{mbp}-\mathrm{Cadm} 4 \mathrm{dCT})$ mutant mice exhibit abnormal distribution of Caspr and aberrant accumulation of Kv1 channels in patches near the juxtaparanodal region and along the internodes. We propose that the reorganization of the axolemma results from the abnormal formation of the mesaxon and the redistribution of Caspr and Kv1 channels from the mesaxonal line. Although yet to be investigated, it is likely that the function of Cadm 4 in axonal organization is different from the one it plays in myelin membrane growth (see below). In support of this idea, it should be noted that similar axonal, but not myelin, abnormalities are also found in mice lacking protein $4.1 \mathrm{G}$, which binds Cadm4 and regulates its expression at the axon-glial interface (Ivanovic et al., 2012).

Cadm4 is thought to mediate axon-glia interaction by binding to axonal Cadm2 and Cadm3 (Maurel et al., 2007; Pellissier et al., 2007; Spiegel et al., 2007). Yet, we found that mice lacking Cadm1, Cadm2, or Cadm3 have normal PNS myelin, suggesting that, in contrast to Cadm4, they are dispensable for PNS myelination. This conclusion is further supported by the observation that double mutant mice lacking Cadm4, together with any other Cadm protein, exhibit myelin abnormalities that were comparable with those found in the single Cadm4-null. Although compensation by other Cadms in these animals cannot be excluded, these results raise the intriguing possibility that Cadm 4 may exert its function by binding to other axonal ligands, or alternatively, by modulating other glia proteins. One potential candidate is erbB2, which is central for PNS myelination (Pereira et al., 2012), and directly interacts with Cadm2 and Cadm4 (Kawano et al., 2009; Mizutani et al., 2011). In addition, it was recently shown that neuregulin induces the association between Cadm1 and erbB4 in hypothalamic astrocytes, further providing a direct link between erbB receptors and Cadm proteins (Sandau et al., 2011). 
A

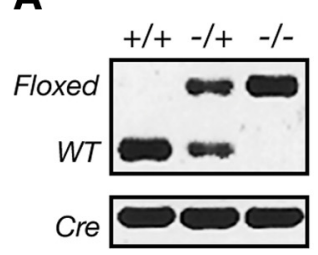

B

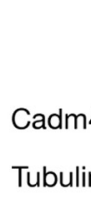

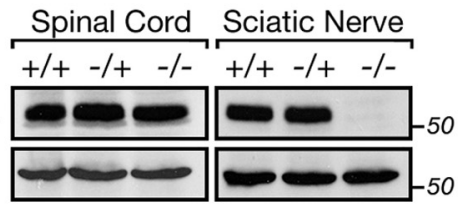

C

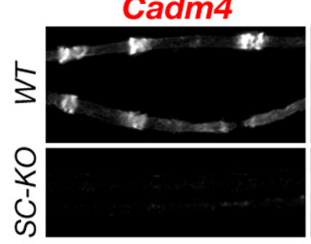

MAG

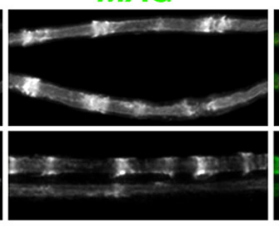

Merged

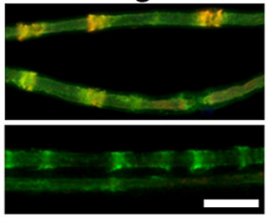

DHH-Cre/Cadm4 $4^{f|f|}$
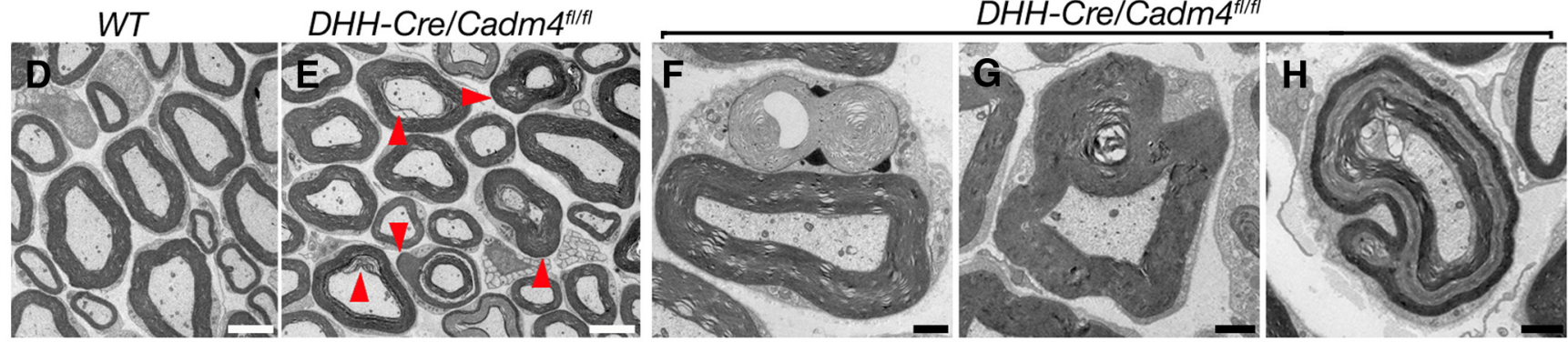

WT

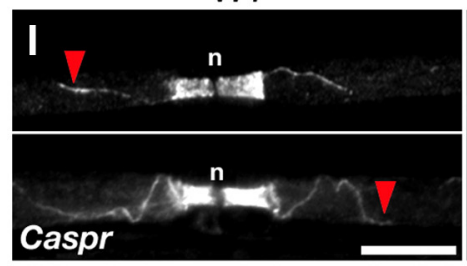

DHH-Cre/Cadm4 $4^{\text {fl/fl}}$

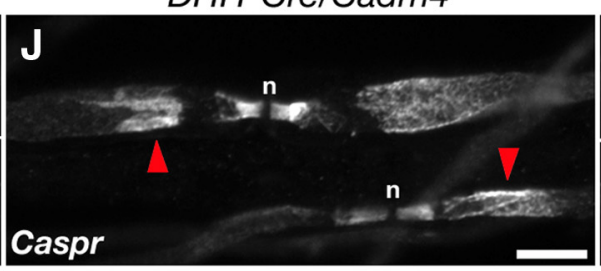

$\mathrm{DHH}-\mathrm{Cre} / \mathrm{Cadm} 4^{\mathrm{fl} / \mathrm{fl}}$

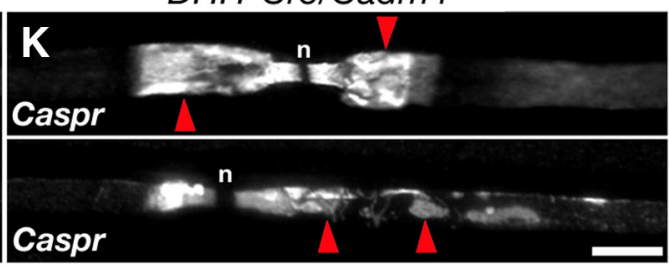

Figure 8. Schwann cell origin of Cadm 4 is required for axonal organization. $A$, RT-PCR analysis of sciatic nerve mRNA isolated from WT $(+/+)$, heterozygous $(-/+)$, or homozygous $\mathrm{DHH}-\mathrm{Cre} / \mathrm{Cadm} 4^{f / f f}(-/-)$ mice, using primer pairs that recognize the floxed and WT alleles, as well as the Cre gene. There is complete absence of a Cadm4 transcript in homozygous mice. $\boldsymbol{B}$, Western blot analysis of sciatic nerves and spinal cord isolated from the indicated genotypes using antibodies to Cadm4 or tubulin as control. No Cadm4 signal is detected in sciatic nerves of homozygous mice, although it is present in their spinal cord. The location of molecular mass markers is indicated on the right in kDa. C, Cadm4 is undetectable in sciatic nerves of DHH-Cre/Cadm4 $4^{f / f / t}$ mice. Teased sciatic nerves isolated from P60 WT, or DHH-Cre/Cadm4 ${ }^{f / f l}$ mice, were immunolabeled using antibodies to Cadm4 and MAG. The merged images are shown on the right. Both Cadm4 and MAG are concentrated in the Schmidt-Lanterman incisures in WT, but Cadm4 immunoreactivity is abolished in DHH-Cre/Cadm4 $4^{f / f l}$ nerves. D, E, Low-magnification EM images of sciatic nerves sections obtained from P30 WT (D) or DHH-Cre/Cadm4 ${ }^{f / f t}$ mice (E). Arrowheads indicate the location of myelin abnormalities. $\boldsymbol{F}-\boldsymbol{H}$, EM images of $D H H$-Cre/Cadm $4^{f / f f l}$ sciatic nerves showing the presence of redundant myelin $(\boldsymbol{F})$, tomacula $(\boldsymbol{G})$, and myelin outfolds $(\boldsymbol{H})$. $\boldsymbol{I}-\boldsymbol{K}$, Schwann cell-specific ablation of Cadm4 results in aberrant axonal organization. Immunolabeling of teased sciatic nerve fibers of WT $(\boldsymbol{I})$ and DHH-Cre/Cadm4 $4^{f / f f}(\boldsymbol{J}, \boldsymbol{K})$ mice showing abnormal accumulation of Caspr (arrowheads) at the juxtaparanodes and internodes. n, Node of Ranvier. Scale bars, $10 \mu \mathrm{m}$.

Furthermore, as myelination downstream of erbB2 is controlled by local phosphoinositide production (Cotter et al., 2010; Goebbels et al., 2012), it is likely that regulation of Schwann cell membrane growth by Cadm 4 is mediated through lipid signaling. In line with this hypothesis, we found that disruption of Cadm4 function results in focal hypermyelination reminiscent of the pathology observed in Charcot-Marie-Tooth neuropathies connected with phosphoinositide metabolism (Bolino et al., 2000; Houlden et al., 2001; Delague et al., 2007; Stendel et al., 2007). Two phosphoinositide signaling pathways that regulate Schwann cell myelination have recently emerged (Masaki, 2012; Pereira et al., 2012). The first is centered around myotubularin-related protein-2 (MTMR2), a phosphatase that dephosphorylates both PtdIns(3)P and PtdIns(3,5)P2 (Bolino et al., 2000; Houlden et al., 2001; Delague et al., 2007; Stendel et al., 2007). MTMR2 associates with Dlg1 (also known as SAP97), a scaffolding protein that in Schwann cells also interacts with the kinesin 13B (kif13B) motor and the exocyte protein Sec8 to regulate vesicular trafficking and local membrane homeostasis (Bolis et al., 2005, 2009). In the absence of functional MTMR2, this homeostasis is disrupted, resulting in focal hypermyelination (Bolino et al., 2004; Bonneick et al., 2005). The second pathway involves the interaction of Dlg1 with another lipid phosphatase, PTEN, which dephosphorylates (PtdIns3,4,5) and antagonizes the function of AKT/PI3K downstream of erbB2 (Pereira et al., 2012). During the first 2 weeks of myelination, Nrg1 type III stabilizes Dlg1 and PTEN complexes by reducing their ubiquitination and proteasomal degradation. This results in an increase in the expression of PTEN, which then negatively regulates myelination and modulating AKT phosphorylation (Cotter et al., 2010). Accordingly, the absence of PTEN in myelinating Schwann cells results in focal hypermyelination and tomaculous neuropathy (Goebbels et al., 2012). The focal abnormalities in myelination (in contrast to global enhancement of myelin thickness) detected in MTMR2, PTEN, as well as Cadm4 mutants, may be the result of the loss of the local negative regulation PTEN exerts in regions of noncompact myelin (Cotter et al., 2010; Goebbels et al., 2012). Although further studies are required to reveal the exact mechanism by which Cadm4 modulates myelin membrane growth, one possibility is that it functions by localizing regulators of membrane homeostasis, such as Dlg1 and PTEN, to their subcellular site of action at the paranodal loops and the Schmidt-Lanterman incisures. In agreement, the abnormal growth of myelin in Cadm 4 mutant mice appears to originate at these two subcellular regions of noncompacted myelin to which PTEN and Dlg1 localize (Ozcelik et al., 2010).

Recent studies suggest that the polarized distribution of intracellular proteins in myelinating Schwann cells is a prerequisite for myelination (Masaki, 2012; for review, see Pereira et al., 2012). In epithelial cells, such polarization is achieved through the recruitment of intracellular scaffolds to specific membrane contact sites by CAMs (Mellman and Nelson, 2008). The cytoplasmic regions 
of Cadm1-Cadm 4 contain binding sites for 4.1 proteins and PDZ domains, two modules that are present in protein scaffolds that could link Cadm 4 to the PTEN and Dlg1 pathways. Notably, Dlg1 contains a 4.1 binding sequence and several PDZ domains, as well as an L27 domain, which mediates the formation of supramolecular scaffolds by binding to other L27-containing proteins (Pieczynski and Margolis, 2011). Myelinating Schwann cells express several other L27 domain-containing proteins, of which Pals1 (Ozcelik et al., 2010), PATJ (Poliak et al., 2002), MUPP1 (Poliak et al., 2002), and Pals2 (Terada et al., 2012), colocalize with Cadm4 in the incisuro-adaxonal domain (Masaki, 2012). MPP1, MPP3, and MPP6, as well as MUPP1 and PATJ, were shown to bind directly to members of the Cadm family (Biederer et al., 2002; Fukuhara et al., 2003; Shingai et al., 2003; Kakunaga et al., 2005; Fujita et al., 2012). Pals2/MPP6, also binds protein $4.1 \mathrm{G}$, a cytoskeletal adapter protein that interacts with Cadm4 (Yang et al., 2011), and is required for the localization of both Cadm4 and Pals2/MPP6 in myelinating Schwann cells (Ivanovic et al., 2012; Terada et al., 2012). Although a direct interaction between Pals 1 and Cadm 4 is yet to be shown, the observation that Pals1 interacts with PATJ (Roh et al., 2002) may suggest the existence of a Cadm4-PATJ-Pals1 complex in myelinating Schwann cells. Notably, knockdown of Pals1 expression resulted in the formation of abnormal myelin infoldings, suggesting that it is required for local myelin membrane production (Ozcelik et al., 2010), a process that is regulated by Dlg1 and PTEN (Cotter et al., 2010; Goebbels et al., 2012). In addition, we note the possibility that Cadm4 could also be connected to the Par3-Par6-aPKC polarity complex, either directly (Fujita et al., 2007) or through PATJ and Pals1 (Plant et al., 2003; Wang et al., 2004). This is of particular interest as it has been demonstrated that Par3 interacts with PTEN (von Stein et al., 2005; Wu et al., 2007; Feng et al., 2008) and targets it to specific membrane domains (Pinal et al., 2006; Feng et al., 2008). Whereas in promyelinating Schwann cells Par3 resides at the axon-glial interface (Chan et al., 2006), in myelinating Schwann cells it is found with Cadm4 at the Schmidt-Lanterman incisures and the paranodal loops (Poliak et al., 2002; Ozcelik et al., 2010), where it may regulate local phosphoinositide signaling and actin dynamics (Song et al., 2012). In accord, Schwann cell-specific deletion of Sirt2, which deacetylates Par3 (and hence activating aPKC), exhibits a transient delay in myelination and focal myelin protrusions as observed in Cadm4 mutants (Beirowski et al., 2011).

In conclusion, by generating mutant mice lacking each of the four Cadm proteins, as well as by expressing a truncated mutant form of Cadm4 in Schwann cells, we found that Cadm4, but not Cadm1, Cadm2, or Cadm3, is required for the proper establishment of myelinated nerves in the PNS. We show that Cadm4 mutant mice develop focal hypermyelination and myelin outfoldings reminiscent of the pathology observed when phosphoinositide metabolism is disrupted. Although further studies are required to clarify the molecular mechanism underlying the function of Cadm4 in myelinating Schwann cells, our results suggest that it may regulate actin cytoskeleton and membrane protrusions by affecting Schwann cell polarization and local phosphoinositide signaling.

\section{References}

Altevogt BM, Kleopa KA, Postma FR, Scherer SS, Paul DL (2002) Connexin29 is uniquely distributed within myelinating glial cells of the central and peripheral nervous systems. J Neurosci 22:6458-6470. Medline

Arroyo EJ, Xu YT, Zhou L, Messing A, Peles E, Chiu SY, Scherer SS (1999) Myelinating Schwann cells determine the internodal localization of
Kv1.1, Kv1.2, Kvbeta2, and Caspr. J Neurocytol 28:333-347. CrossRef Medline

Beirowski B, Gustin J, Armour SM, Yamamoto H, Viader A, North BJ, Michán S, Baloh RH, Golden JP, Schmidt RE, Sinclair DA, Auwerx J, Milbrandt J (2011) Sir-two-homolog 2 (Sirt2) modulates peripheral myelination through polarity protein Par-3/atypical protein kinase C (aPKC) signaling. Proc Natl Acad Sci U S A 108:E952-E961. CrossRef Medline

Biederer T (2006) Bioinformatic characterization of the SynCAM family of immunoglobulin-like domain-containing adhesion molecules. Genomics 87:139-150. CrossRef Medline

Biederer T, Sara Y, Mozhayeva M, Atasoy D, Liu X, Kavalali ET, Südhof TC (2002) SynCAM, a synaptic adhesion molecule that drives synapse assembly. Science 297:1525-1531. CrossRef Medline

Bolino A, Muglia M, Conforti FL, LeGuern E, Salih MA, Georgiou DM, Christodoulou K, Hausmanowa-Petrusewicz I, Mandich P, Schenone A, Gambardella A, Bono F, Quattrone A, Devoto M, Monaco AP (2000) Charcot-Marie-Tooth type $4 \mathrm{~B}$ is caused by mutations in the gene encoding myotubularin-related protein-2. Nat Genet 25:17-19. CrossRef Medline

Bolino A, Bolis A, Previtali SC, Dina G, Bussini S, Dati G, Amadio S, Del Carro U, Mruk DD, Feltri ML, Cheng CY, Quattrini A, Wrabetz L (2004) Disruption of Mtmr2 produces CMT4B1-like neuropathy with myelin outfolding and impaired spermatogenesis. J Cell Biol 167:711-721. CrossRef Medline

Bolis A, Coviello S, Bussini S, Dina G, Pardini C, Previtali SC, Malaguti M, Morana P, Del Carro U, Feltri ML, Quattrini A, Wrabetz L, Bolino A (2005) Loss of Mtmr2 phosphatase in Schwann cells but not in motor neurons causes Charcot-Marie-Tooth type 4B1 neuropathy with myelin outfoldings. J Neurosci 25:8567-8577. CrossRef Medline

Bolis A, Coviello S, Visigalli I, Taveggia C, Bachi A, Chishti AH, Hanada T, Quattrini A, Previtali SC, Biffi A, Bolino A (2009) Dlg1, Sec8, and Mtmr2 regulate membrane homeostasis in Schwann cell myelination. J Neurosci 29:8858-8870. CrossRef Medline

Bonneick S, Boentert M, Berger P, Atanasoski S, Mantei N, Wessig C, Toyka KV, Young P, Suter U (2005) An animal model for Charcot-MarieTooth disease type 4B1. Hum Mol Genet 14:3685-3695. CrossRef Medline

Chan JR, Jolicoeur C, Yamauchi J, Elliott J, Fawcett JP, Ng BK, Cayouette M (2006) The polarity protein Par-3 directly interacts with p75NTR to regulate myelination. Science 314:832-836. CrossRef Medline

Cotter L, Ozçelik M, Jacob C, Pereira JA, Locher V, Baumann R, Relvas JB, Suter U, Tricaud N (2010) Dlg1-PTEN interaction regulates myelin thickness to prevent damaging peripheral nerve overmyelination. Science 328:1415-1418. CrossRef Medline

Court FA, Wrabetz L, Feltri ML (2006) Basal lamina: Schwann cells wrap to the rhythm of space-time. Curr Opin Neurobiol 16:501-507. CrossRef Medline

Delague V, Jacquier A, Hamadouche T, Poitelon Y, Baudot C, Boccaccio I, Chouery E, Chaouch M, Kassouri N, Jabbour R, Grid D, Mégarbané A, Haase G, Lévy N (2007) Mutations in FGD4 encoding the Rho GDP/ GTP exchange factor FRABIN cause autosomal recessive Charcot-MarieTooth type 4H. Am J Hum Genet 81:1-16. CrossRef Medline

Einheber S, Zanazzi G, Ching W, Scherer S, Milner TA, Peles E, Salzer JL (1997) The axonal membrane protein Caspr, a homologue of neurexin IV, is a component of the septate-like paranodal junctions that assemble during myelination. J Cell Biol 139:1495-1506. CrossRef Medline

Eshed Y, Feinberg K, Poliak S, Sabanay H, Sarig-Nadir O, Spiegel I, Bermingham JR Jr, Peles E (2005) Gliomedin mediates Schwann cell-axon interaction and the molecular assembly of the nodes of Ranvier. Neuron 47: 215-229. CrossRef Medline

Fannon AM, Sherman DL, Ilyina-Gragerova G, Brophy PJ, Friedrich VL Jr, Colman DR (1995) Novel E-cadherin-mediated adhesion in peripheral nerve: Schwann cell architecture is stabilized by autotypic adherens junctions. J Cell Biol 129:189-202. CrossRef Medline

Farhadi HF, Lepage P, Forghani R, Friedman HC, Orfali W, Jasmin L, Miller W, Hudson TJ, Peterson AC (2003) A combinatorial network of evolutionarily conserved myelin basic protein regulatory sequences confers distinct glial-specific phenotypes. J Neurosci 23:10214-10223. Medline

Farley FW, Soriano P, Steffen LS, Dymecki SM (2000) Widespread recombinase expression using FLPeR (flipper) mice. Genesis 28:106-110. CrossRef Medline 
Feinberg K, Eshed-Eisenbach Y, Frechter S, Amor V, Salomon D, Sabanay H, Dupree JL, Grumet M, Brophy PJ, Shrager P, Peles E (2010) A glial signal consisting of gliomedin and NrCAM clusters axonal $\mathrm{Na}+$ channels during the formation of nodes of Ranvier. Neuron 65:490-502. CrossRef Medline

Feng W, Wu H, Chan LN, Zhang M (2008) Par-3-mediated junctional localization of the lipid phosphatase PTEN is required for cell polarity establishment. J Biol Chem 283:23440-23449. CrossRef Medline

Fujita E, Urase K, Soyama A, Kouroku Y, Momoi T (2005) Distribution of RA175/TSLC1/SynCAM, a member of the immunoglobulin superfamily, in the developing nervous system. Brain Res Dev Brain Res 154:199-209. CrossRef Medline

Fujita E, Tanabe Y, Hirose T, Aurrand-Lions M, Kasahara T, Imhof BA, Ohno S, Momoi T (2007) Loss of partitioning-defective-3/isotype-specific interacting protein (par-3/ASIP) in the elongating spermatid of RA175 (IGSF4A/SynCAM)-deficient mice. Am J Pathol 171:1800-1810. CrossRef Medline

Fujita E, Tanabe Y, Imhof BA, Momoi MY, Momoi T (2012) A complex of synaptic adhesion molecule CADM1, a molecule related to autism spectrum disorder, with MUPP1 in the cerebellum. J Neurochem 123: 886-894. CrossRef Medline

Fukuhara H, Masuda M, Yageta M, Fukami T, Kuramochi M, Maruyama T, Kitamura T, Murakami Y, Masvuda M (2003) Association of a lung tumor suppressor TSLC1 with MPP3, a human homologue of Drosophila tumor suppressor Dlg. Oncogene 22:6160-6165. CrossRef Medline

Goebbels S, Oltrogge JH, Wolfer S, Wieser GL, Nientiedt T, Pieper A, Ruhwedel T, Groszer M, Sereda MW, Nave KA (2012) Genetic disruption of Pten in a novel mouse model of tomaculous neuropathy. EMBO Mol Med 4:486-499. CrossRef Medline

Gollan L, Sabanay H, Poliak S, Berglund EO, Ranscht B, Peles E (2002) Retention of a cell adhesion complex at the paranodal junction requires the cytoplasmic region of Caspr. J Cell Biol 157:1247-1256. CrossRef Medline

Horn M, Baumann R, Pereira JA, Sidiropoulos PN, Somandin C, Welzl H, Stendel C, Lühmann T, Wessig C, Toyka KV, Relvas JB, Senderek J, Suter $\mathrm{U}$ (2012) Myelin is dependent on the Charcot-Marie-Tooth Type $4 \mathrm{H}$ disease culprit protein FRABIN/FGD4 in Schwann cells. Brain 135:35673583. CrossRef Medline

Houlden H, King RH, Wood NW, Thomas PK, Reilly MM (2001) Mutations in the $5^{\prime}$ region of the myotubularin-related protein 2 (MTMR2) gene in autosomal recessive hereditary neuropathy with focally folded myelin. Brain 124:907-915. CrossRef Medline

Huxley C, Passage E, Manson A, Putzu G, Figarella-Branger D, Pellissier JF, Fontés M (1996) Construction of a mouse model of Charcot-MarieTooth disease type 1A by pronuclear injection of human YAC DNA. Hum Mol Genet 5:563-569. CrossRef Medline

Ivanovic A, Horresh I, Golan N, Spiegel I, Sabanay H, Frechter S, Ohno S, Terada N, Möbius W, Rosenbluth J, Brose N, Peles E (2012) The cytoskeletal adapter protein $4.1 \mathrm{G}$ organizes the internodes in peripheral myelinated nerves. J Cell Biol 196:337-344. CrossRef Medline

Jaegle M, Ghazvini M, Mandemakers W, Piirsoo M, Driegen S, Levavasseur F, Raghoenath S, Grosveld F, Meijer D (2003) The POU proteins Brn-2 and Oct-6 share important functions in Schwann cell development. Genes Dev 17:1380-1391. CrossRef Medline

Jessen KR, Mirsky R (2005) The origin and development of glial cells in peripheral nerves. Nat Rev Neurosci 6:671-682. CrossRef Medline

Kakunaga S, Ikeda W, Itoh S, Deguchi-Tawarada M, Ohtsuka T, Mizoguchi A, Takai Y (2005) Nectin-like molecule-1/TSLL1/SynCAM3: a neural tissue-specific immunoglobulin-like cell-cell adhesion molecule localizing at non-junctional contact sites of presynaptic nerve terminals, axons and glia cell processes. J Cell Sci 118:1267-1277. CrossRef Medline

Kawano S, Ikeda W, Kishimoto M, Ogita H, Takai Y (2009) Silencing of ErbB3/ErbB2 signaling by immunoglobulin-like Necl-2. J Biol Chem 284: 23793-23805. CrossRef Medline

Kikuchi S, Ninomiya T, Tatsumi H, Sawada N, Kojima T (2010) Tricellulin is expressed in autotypic tight junctions of peripheral myelinating Schwann cells. J Histochem Cytochem 58:1067-1073. CrossRef Medline

Kinter J, Lazzati T, Schmid D, Zeis T, Erne B, Lützelschwab R, Steck AJ, Pareyson D, Peles E, Schaeren-Wiemers N (2012) An essential role of MAG in mediating axon-myelin attachment in Charcot-Marie-Tooth 1A disease. Neurobiol Dis 49C:221-231. CrossRef Medline

Knott G, Marchman H, Wall D, Lich B (2008) Serial section scanning elec- tron microscopy of adult brain tissue using focused ion beam milling. J Neurosci 28:2959-2964. CrossRef Medline

Lallemand Y, Luria V, Haffner-Krausz R, Lonai P (1998) Maternally expressed PGK-Cre transgene as a tool for early and uniform activation of the Cre site-specific recombinase. Transgenic Res 7:105-112. CrossRef Medline

Lustig M, Zanazzi G, Sakurai T, Blanco C, Levinson SR, Lambert S, Grumet M, Salzer JL (2001) Nr-CAM and neurofascin interactions regulate ankyrin $\mathrm{G}$ and sodium channel clustering at the node of Ranvier. Curr Biol 11:1864-1869. CrossRef Medline

Masaki T (2012) Polarization and myelination in myelinating glia. ISRN Neurol 2012:769412. CrossRef Medline

Maurel P, Einheber S, Galinska J, Thaker P, Lam I, Rubin MB, Scherer SS, Murakami Y, Gutmann DH, Salzer JL (2007) Nectin-like proteins mediate axon Schwann cell interactions along the internode and are essential for myelination. J Cell Biol 178:861-874. CrossRef Medline

Mellman I, Nelson WJ (2008) Coordinated protein sorting, targeting and distribution in polarized cells. Nat Rev Mol Cell Biol 9:833-845. CrossRef Medline

Miyamoto T, Morita K, Takemoto D, Takeuchi K, Kitano Y, Miyakawa T, Nakayama K, Okamura Y, Sasaki H, Miyachi Y, Furuse M, Tsukita S (2005) Tight junctions in Schwann cells of peripheral myelinated axons: a lesson from claudin-19-deficient mice. J Cell Biol 169:527-538. CrossRef Medline

Mizutani K, Kawano S, Minami A, Waseda M, Ikeda W, Takai Y (2011) Interaction of nectin-like molecule 2 with integrin alpha6beta4 and inhibition of disassembly of integrin alpha6beta4 from hemidesmosomes. J Biol Chem 286:36667-36676. CrossRef Medline

Novak N, Bar V, Sabanay H, Frechter S, Jaegle M, Snapper SB, Meijer D, Peles E (2011) N-WASP is required for membrane wrapping and myelination by Schwann cells. J Cell Biol 192:243-250. CrossRef Medline

Ozçelik M, Cotter L, Jacob C, Pereira JA, Relvas JB, Suter U, Tricaud N (2010) Pals1 is a major regulator of the epithelial-like polarization and the extension of the myelin sheath in peripheral nerves. J Neurosci 30: 4120-4131. CrossRef Medline

Park J, Liu B, Chen T, Li H, Hu X, Gao J, Zhu Y, Zhu Q, Qiang B, Yuan J, Peng X, Qiu M (2008) Disruption of Nectin-like 1 cell adhesion molecule leads to delayed axonal myelination in the CNS. J Neurosci 28:1281512819. CrossRef Medline

Pedraza L, Owens GC, Green LA, Salzer JL (1990) The myelin-associated glycoproteins: membrane disposition, evidence of a novel disulfide linkage between immunoglobulin-like domains, and posttranslational palmitylation. J Cell Biol 111:2651-2661. CrossRef Medline

Peles E, Nativ M, Lustig M, Grumet M, Schilling J, Martinez R, Plowman GD, Schlessinger J (1997) Identification of a novel contactin-associated transmembrane receptor with multiple domains implicated in proteinprotein interactions. EMBO J 16:978-988. CrossRef Medline

Pellissier F, Gerber A, Bauer C, Ballivet M, Ossipow V (2007) The adhesion molecule Necl-3/SynCAM-2 localizes to myelinated axons, binds to oligodendrocytes and promotes cell adhesion. BMC Neurosci 8:90. CrossRef Medline

Pereira JA, Lebrun-Julien F, Suter U (2012) Molecular mechanisms regulating myelination in the peripheral nervous system. Trends Neurosci 35: 123-134. CrossRef Medline

Pieczynski J, Margolis B (2011) Protein complexes that control renal epithelial polarity. Am J Physiol Renal Physiol 300:F589-F601. CrossRef Medline

Pinal N, Goberdhan DC, Collinson L, Fujita Y, Cox IM, Wilson C, Pichaud F (2006) Regulated and polarized PtdIns(3,4,5)P3 accumulation is essential for apical membrane morphogenesis in photoreceptor epithelial cells. Curr Biol 16:140-149. CrossRef Medline

Plant PJ, Fawcett JP, Lin DC, Holdorf AD, Binns K, Kulkarni S, Pawson T (2003) A polarity complex of mPar-6 and atypical PKC binds, phosphorylates and regulates mammalian Lgl. Nat Cell Biol 5:301-308. CrossRef Medline

Poliak S, Peles E (2003) The local differentiation of myelinated axons at nodes of Ranvier. Nat Rev Neurosci 4:968-980. CrossRef Medline

Poliak S, Gollan L, Martinez R, Custer A, Einheber S, Salzer JL, Trimmer JS, Shrager P, Peles E (1999) Caspr2, a new member of the neurexin superfamily, is localized at the juxtaparanodes of myelinated axons and associates with K+ channels. Neuron 24:1037-1047. CrossRef Medline

Poliak S, Matlis S, Ullmer C, Scherer SS, Peles E (2002) Distinct claudins and 
associated PDZ proteins form different autotypic tight junctions in myelinating Schwann cells. J Cell Biol 159:361-372. CrossRef Medline

Roh MH, Makarova O, Liu CJ, Shin K, Lee S, Laurinec S, Goyal M, Wiggins R, Margolis B (2002) The Maguk protein, Pals1, functions as an adapter, linking mammalian homologues of Crumbs and Discs Lost. J Cell Biol 157:161-172. CrossRef Medline

Sandau US, Mungenast AE, McCarthy J, Biederer T, Corfas G, Ojeda SR (2011) The synaptic cell adhesion molecule, SynCAM1, mediates astrocyte-to-astrocyte and astrocyte-to-GnRH neuron adhesiveness in the mouse hypothalamus. Endocrinology 152:2353-2363. CrossRef Medline

Scheiermann C, Meda P, Aurrand-Lions M, Madani R, Yiangou Y, Coffey P, Salt TE, Ducrest-Gay D, Caille D, Howell O, Reynolds R, Lobrinus A, Adams RH, Yu AS, Anand P, Imhof BA, Nourshargh S (2007) Expression and function of junctional adhesion molecule- $\mathrm{C}$ in myelinated peripheral nerves. Science 318:1472-1475. CrossRef Medline

Scherer SS, Arroyo EJ (2002) Recent progress on the molecular organization of myelinated axons. J Peripher Nerv Syst 7:1-12. CrossRef Medline

Shingai T, Ikeda W, Kakunaga S, Morimoto K, Takekuni K, Itoh S, Satoh K, Takeuchi M, Imai T, Monden M, Takai Y (2003) Implications of nectinlike molecule-2/IGSF4/RA175/SgIGSF/TSLC1/SynCAM1 in adhesion and transmembrane protein localization in epithelial cells. J Biol Chem 278:35421-35427. CrossRef Medline

Song MS, Salmena L, Pandolfi PP (2012) The functions and regulation of the PTEN tumour suppressor. Nat Rev Mol Cell Biol 13:283-296. CrossRef Medline

Spiegel I, Peles E (2002) Cellular junctions of myelinated nerves (Review). Mol Membr Biol 19:95-101. CrossRef Medline

Spiegel I, Adamsky K, Eshed Y, Milo R, Sabanay H, Sarig-Nadir O, Horresh I, Scherer SS, Rasband MN, Peles E (2007) A central role for Necl4 (SynCAM4) in Schwann cell-axon interaction and myelination. Nat Neurosci 10:861-869. CrossRef Medline

Stendel C, Roos A, Deconinck T, Pereira J, Castagner F, Niemann A, Kirschner J, Korinthenberg R, Ketelsen UP, Battaloglu E, Parman Y, Nicholson G, Ouvrier R, Seeger J, De Jonghe P, Weis J, Kruttgen A, RudnikSchöneborn S, Bergmann C, Suter U, et al. (2007) Peripheral nerve demyelination caused by a mutant Rho GTPase guanine nucleotide exchange factor, frabin/FGD4. Am J Hum Genet 81:158-164. CrossRef Medline

Susuki K, Rasband MN (2008) Molecular mechanisms of node of Ranvier formation. Curr Opin Cell Biol 20:616-623. CrossRef Medline

Susuki K, Raphael AR, Ogawa Y, Stankewich MC, Peles E, Talbot WS, Rasband MN (2011) Schwann cell spectrins modulate peripheral nerve myelination. Proc Natl Acad Sci U S A 108:8009-8014. CrossRef Medline

Tait S, Gunn-Moore F, Collinson JM, Huang J, Lubetzki C, Pedraza L, Sherman DL, Colman DR, Brophy PJ (2000) An oligodendrocyte cell adhesion molecule at the site of assembly of the paranodal axo-glial junction. J Cell Biol 150:657-666. CrossRef Medline

Takai Y, Miyoshi J, Ikeda W, Ogita H (2008) Nectins and nectin-like molecules: roles in contact inhibition of cell movement and proliferation. Nat Rev Mol Cell Biol 9:603-615. CrossRef Medline

Terada N, Saitoh Y, Ohno N, Komada M, Saitoh S, Peles E, Ohno S (2012) Essential function of protein $4.1 \mathrm{G}$ in targeting of membrane protein palmitoylated 6 into Schmidt-Lanterman incisures in myelinated nerves. Mol Cell Biol 32:199-205. CrossRef Medline

Tersar K, Boentert M, Berger P, Bonneick S, Wessig C, Toyka KV, Young P, Suter U (2007) Mtmr13/Sbf2-deficient mice: an animal model for CMT4B2. Hum Mol Genet 16:2991-3001. CrossRef Medline

von Stein W, Ramrath A, Grimm A, Müller-Borg M, Wodarz A (2005) Direct association of Bazooka/PAR-3 with the lipid phosphatase PTEN reveals a link between the PAR/aPKC complex and phosphoinositide signaling. Development 132:1675-1686. CrossRef Medline

Wang Q, Hurd TW, Margolis B (2004) Tight junction protein Par6 interacts with an evolutionarily conserved region in the amino terminus of PALS1/ stardust. J Biol Chem 279:30715-30721. CrossRef Medline

Wu H, Feng W, Chen J, Chan LN, Huang S, Zhang M (2007) PDZ domains of Par-3 as potential phosphoinositide signaling integrators. Mol Cell 28:886-898. CrossRef Medline

Yang S, Weng H, Chen L, Guo X, Parra M, Conboy J, Debnath G, Lambert AJ, Peters LL, Baines AJ, Mohandas N, An X (2011) Lack of protein 4.1G causes altered expression and localization of the cell adhesion molecule nectin-like 4 in testis and can cause male infertility. Mol Cell Biol 31:2276-2286. CrossRef Medline 